\title{
The role of canopy gaps in maintaining biodiversity of plants and soil macrofauna in the forests of the northwestern Caucasus
}

\author{
Nikolaj Shevchenko ${ }^{1}$, Anna Geraskina ${ }^{1 *}$, Alexander Kuprin², Evgeniy Grabenko ${ }^{3}$ \\ ${ }^{1}$ Center for Forest Ecology and Productivity Russian Academy of Sciences, Moscow, Russian Federation \\ ${ }^{2}$ Federal Scientific Center of the East Asia Terrestrial Biodiversity, Far Eastern Branch Russian Academy of Sciences, \\ Vladivostok, Russian Federation \\ ${ }^{3}$ Institute of Geography Russian Academy of Sciences, Russian Federation \\ "corresponding author e-mail: angersgma@gmail.com
}

Received: 23 April 2020 / Accepted: 23 December 2020

\begin{abstract}
The research was carried out in the coniferous-deciduous forests of the northwestern Caucasus, growing in similar climatic and soil-orographic conditions. Three types of forests of different ages were studied: aspen-hornbeam (50-70 years), beech-firhornbeam (80-110 years) and fir-beech forests (over 450 years). The studies were performed on the territory Krasnodar Krai (upper reaches of the Pshekha river, State Nature Reserve Chernogor'e) and the Republic of Adygea (upper reaches of the Belaya river, the Caucasian State Biosphere Reserve) in the summer seasons 2016 and 2019. The research involves geobotanical, population-ontogenetic, and soil-zoological methods. It has been established that in the canopy gaps of all forest types species density of plants is almost twice as high as in under-crown areas or even higher due to good light factor and high soil moisture since the tree stand does not intercept precipitation. Regeneration of tree cenopopulations in all forest types is much more effective in canopy gaps compared to under-crown areas. The undergrowth density of different types of trees is 10 and more times higher in gaps than in the under-crown areas. The maximum number of ecological-coenotic groups of plants is observed in the canopy gaps in all types of forest. All major trophic groups of macrofauna inhabit canopy gaps and under-crown areas, but their biomass in gaps is significantly exceeds that in under-crown areas. Due to the fact that soil moisture supply is an essential factor for moisture-loving saprophages' activity, biomass of saprophages is on average twice as high in gaps than under-crown areas of all forest types. Only canopy gaps have high biomass of anecic earthworms - there are important ecosystem engineers, which contribute a lot to plant litter processing and the formation of soil porosity.
\end{abstract}

Keywords: earthworms, forest community, invertebrates, species richness, treefall gaps, trophic groups, saprophages, under-crown area, undergrowth.

\section{Introduction}

Gap dynamics model defines the self-support capabilities of forests (Watt, 1947; Oldeman, 1983; Whitmore, 1990). In this model, forests are shown as a mosaic of spots of different ages with a continuous change in the vegetation species composition. It has been shown that the canopies of various tree species can act as ecological filters (Gandolfi et al., 2007) for vegetation renewal. There are obvi- ous differences in the conditions for plant growth under the canopy of deciduous and coniferous tree species. However, drastic changes in the light and precipitation mode occur after the fall of old trees and canopy gaps formation. Great attention is currently being paid to the role of canopy gaps in maintaining biological (Bartemucci et al., 2002) and structural diversity (Zhang et al., 2013; Muscolo et al., 2014) of forest communities and application this knowledge in forest management practices (Vajari et al., 2012; 
Yamamoto, 1996; Rebertus \& Veblen, 1993; Runkle, 2000; Haghverdi et al., 2012; etc.). The area of natural canopy gaps according to literature can range from 200 to $5.000 \mathrm{~m}^{2}$ (Muscolo et al., 2014), the average gap size for Eastern European forests is between 200 and $600 \mathrm{~m}^{2}$ (Smirnova et al., 2004). It has been shown that gap size also determines the structural and functional diversity of the soil macrofauna (Kooch \& Hosseini, 2010; Kooch \& Haghverdi, 2014), particularly that of soil saprophages, which act as a driver of litter decay. Assessing of and forecasting the sustainable development of forest ecosystems requires linked studies of transformation of vegetation and large soil macrofauna that mediates the influence of vegetation on soil properties through the quality of litter (Frouz et al., 2013). Due to the fact that undercrown spaces and gaps differ in light factor and the amount of precipitation, it can be assumed that the diversity and composition of functional groups of plants and soil macrofauna will differ between these structural elements. The diversity of some plant and invertebrate groups can be expected to be higher in gaps than under canopy.

The objective of the work is to assess the contribution of gaps to the maintenance of structural and biological diversity of vegetation and soil macrofauna of mixed coniferous-broad leaved forests of the northwestern Caucasus.

\section{Study area}

The research was carried out in the upper reaches of the Pshekha river (Krasnodar Krai) and the Belaya river (Republic of Adygea, Caucasian State Biosphere Reserve) (Fig. 1). This territory is part of the Western mountain province of the Greater Caucasus (Gvozdetsky, 1963; Milkov \& Gvozdetsky, 1986). Average annual precipitation is $1.200 \mathrm{~mm}$. Average annual temperature is $+10.3^{\circ} \mathrm{C}$. Positive air temperatures remain for 292-361 days, and the growth season $\left(\mathrm{T}>10^{\circ} \mathrm{C}\right)$ is $160-234$ days (http://meteo.ru). The relief is complex: from the pronounced Alpine relief in the upper reaches of the Belaya river, composed of clay shales and limestones, to the relatively flat foothill in the upper reaches of the Pshekha river, composed of clay and crystal shales. High ruggedness of the mountain topography and elevation differences cause vertical variability of all climate indicators. Schist eluvia-based brown soils (Cambisols Dystric, WRB..., 2015) are common in the soil cover. The thickness of the humus horizon is on average $10-15 \mathrm{~cm}$, humus content in the upper horizon can reach $10-15 \%$, $\mathrm{pH}$ is acidic or slightly acidic (Shishov et al., 2004).

In similar climatic and soil-orographic conditions three types of coniferous-deciduous forests of the northwestern Caucasus, i.e. aspen-hornbeam, beech-fir-hornbeam and fir-beech forests, were selected as the object of research (Fig. 2).

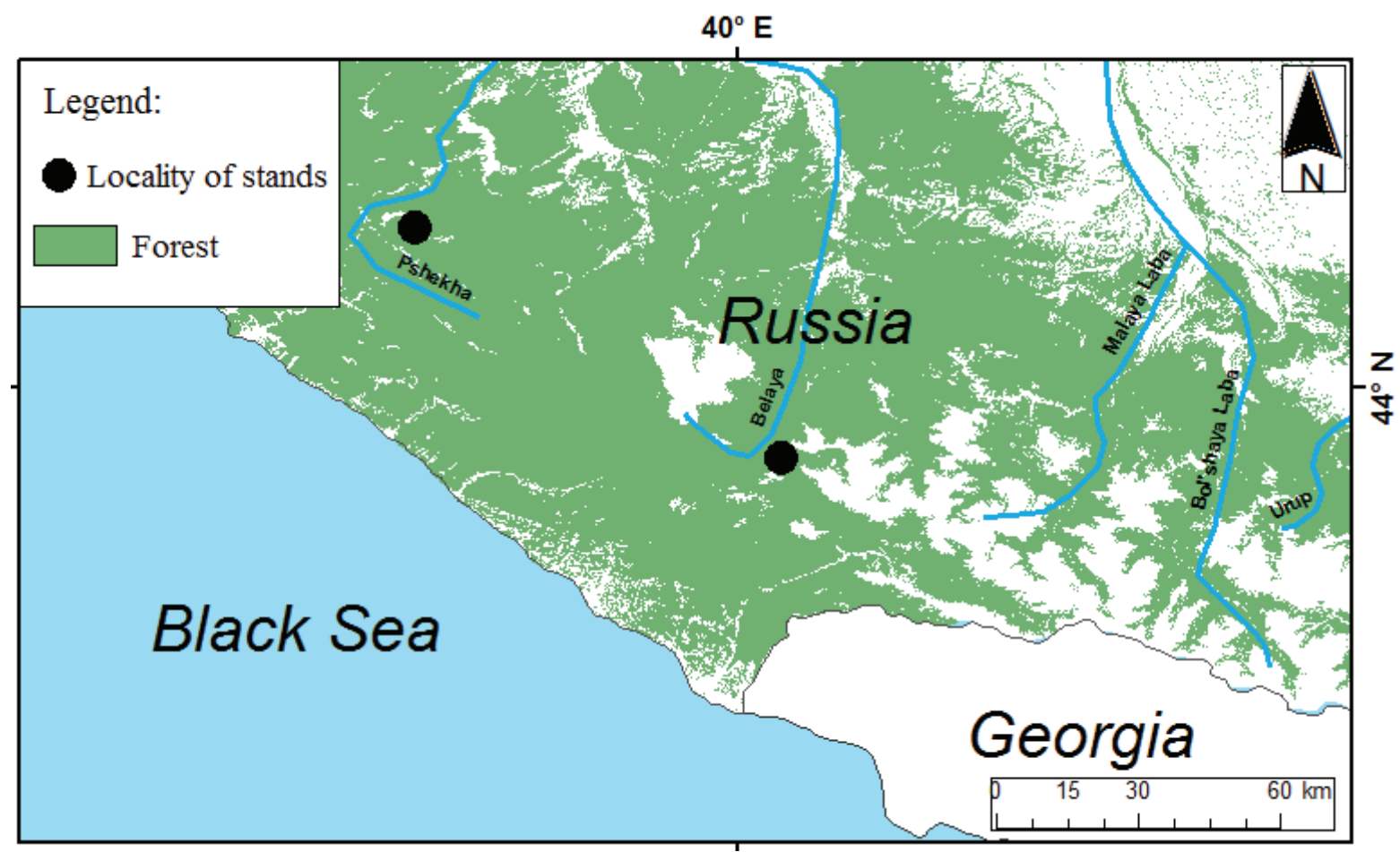

Figure 1. Map of the study area and location of forest stands 


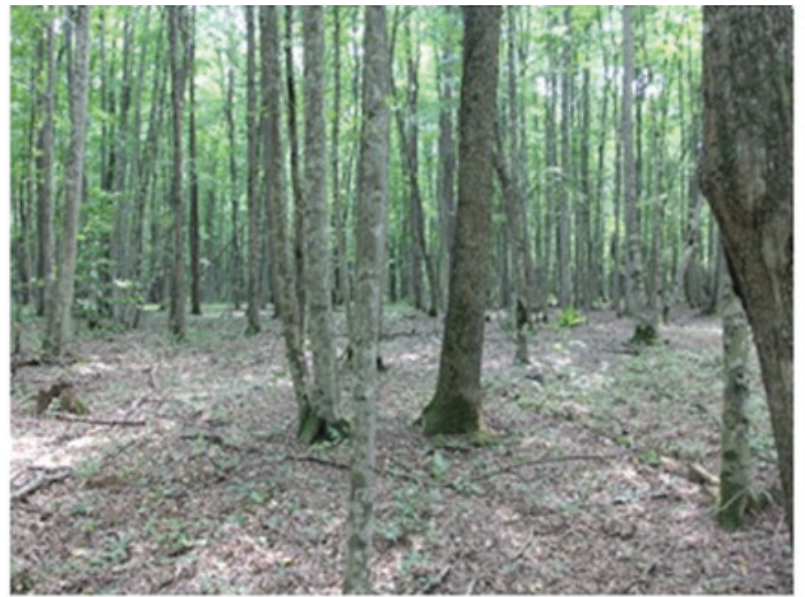

1

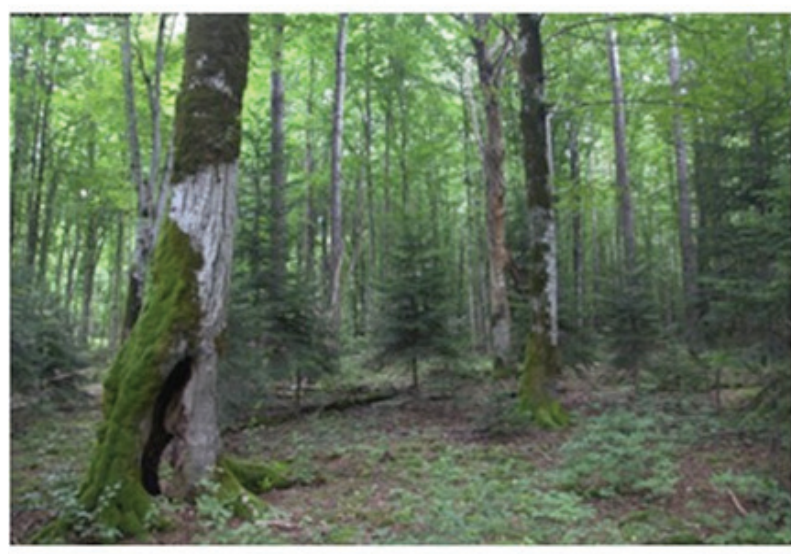

3

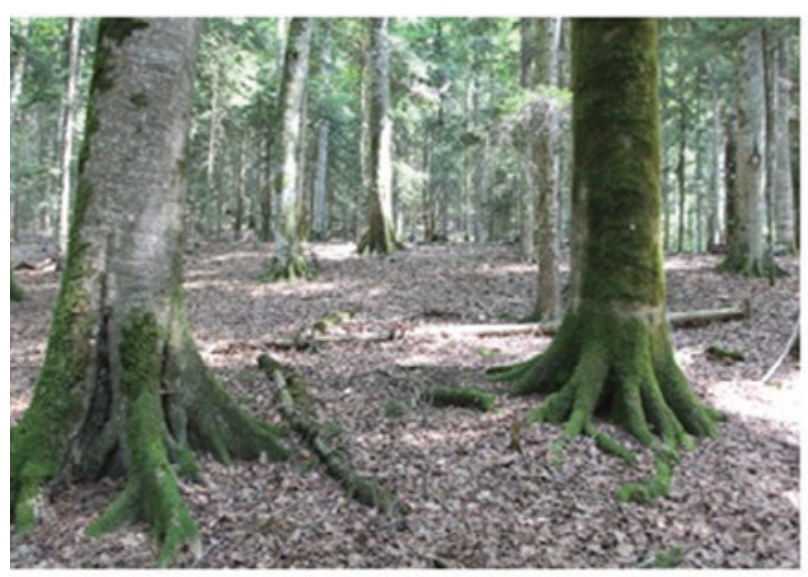

5

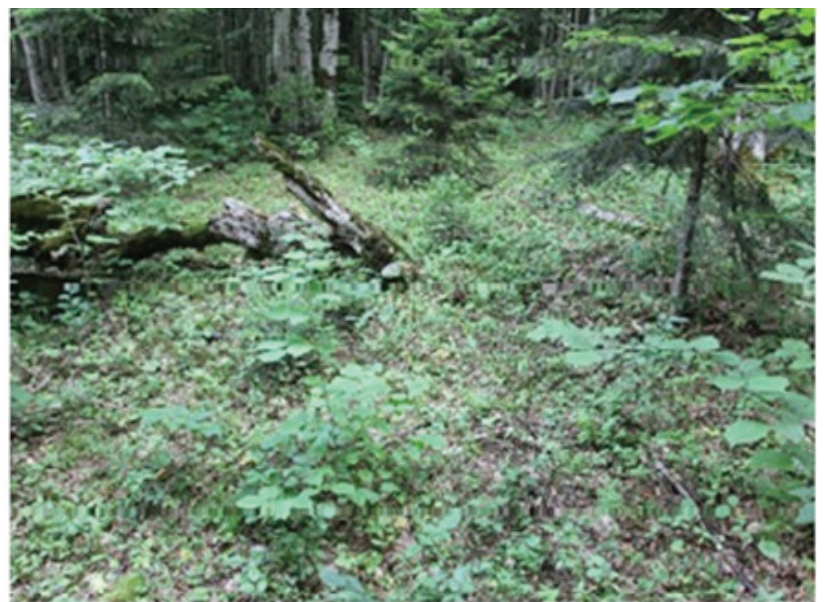

2

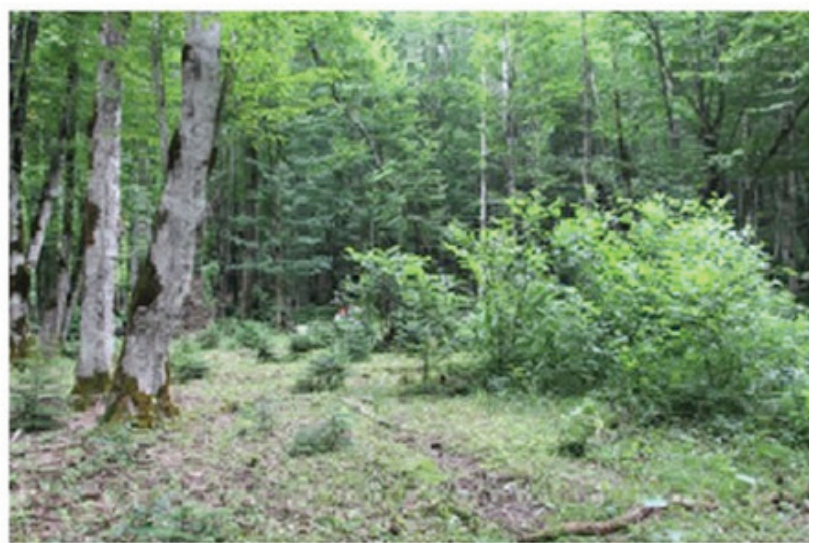

4

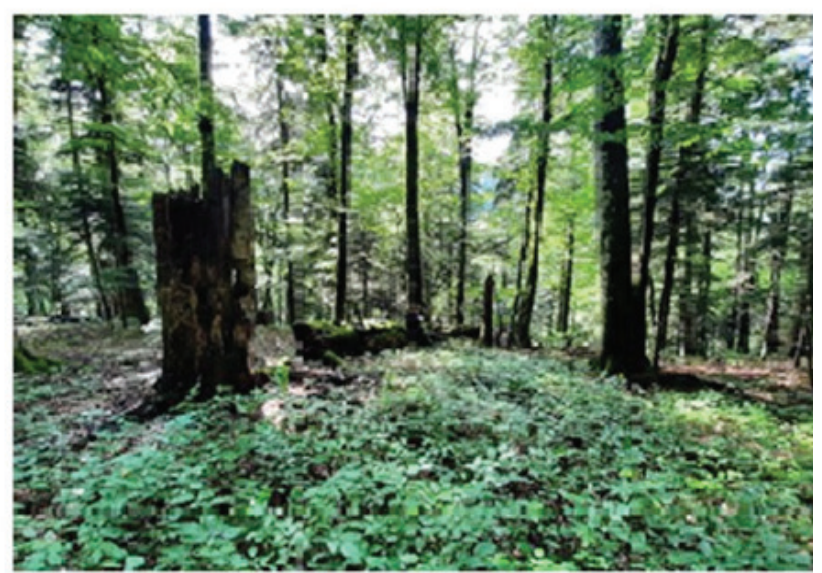

6

Figure 2. Under-crown areas and canopy gaps of coniferous-deciduous forests of the northwestern Caucasus. Plant communities of: 1 - under-crown area aspen-hornbeam forest type; 2 - canopy gap aspen-hornbeam forest type; 3 - under-crown area beech-fir-hornbeam type of forest; 4 - canopy gap beech-fir-hornbeam type of forest; 5 - under-crown area fir-beech forest type; 6 - canopy gap fir-beech forest type 


\section{Materials and Methods}

\subsection{Characteristics of forest types}

The aspen-hornbeam forest type is formed after clear and selective logging, the maximum age of trees is 50-70 years, the height of the tree canopy is $22 \pm 3.7$ meters, the average stock of stem wood is $293 \pm 34 \mathrm{~m}^{3} / \mathrm{ha}$, of which Carpinus betulus accounts for about $60-75 \%$ of the stock and Populus tremula - for about $10-20 \%$ of the stock, whereas the share of other species is less than 10-5\% (Lukina et al., 2018).

The beech-fir-hornbeam type of forest is formed on the sites of old clear and selective loggings, the maximum age of trees of the first post-harvest generation is $80-110$ years, the height of the stand is $32 \pm 5.7$ meters. The average stock of stem wood is $319 \pm 87 \mathrm{~m}^{3} / \mathrm{ha}$, with Carpinus betulus accounting for $40-50 \%$ of the total wood stock, Abies nordmanniana - for 20-30\% and Fagus orientalis - for $20-25 \%$. In the beech-fir-hornbeam type of forest, there is a gradual loss of light demanding tree species that formed the first post-harvest generation. The upper tree layer includes young shade-tolerant trees of Abies nordmanniana and Fagus orientalis (Lukina et al., 2018).

The fir-beech forest type is characterized by the absence of traces of logging or fire (no coal was found in soil), the tree layer has a complex spatial structure and is represented by trees of different ages. This type of forest was described on the territory of the Caucasian biosphere reserve which has preserved well since the end of the 18th century, so the remaining local forests are the closest to natural ones. The age of individual fir trees exceeds 450 years; the height of the tree canopy reaches $50 \pm 12.1$ meters. The average stock of stem wood is $1.097 \pm 265 \mathrm{~m}^{3} / \mathrm{ha}$, with Fagus orientalis accounting for 66 to $82 \%$ of the total stock of stem wood, and Abies nordmanniana accounting for 16 to $32 \%$ (Lukina et al., 2018).

According to the ecological and floristic classification, these forests belong to different associations of AbietiFagenion orientalis sub-union Korotkov et Belonovskaja 1987 of Vaccinio-Fagion orientalis union (Zohary, 1973) Passarge 1981 of Rhododendro pontici-Fagetalia orientalis order (Soo, 1964) Pass. 1981, of Querco-Fagetea class Br.B1. et Vlieger 1937.

This research was conducted in the summer seasons of 2016 and 2019. The study involved geobotanical, population-ontogenetic, and soil-zoological methods.

\subsection{Geobotanical methods}

Square plots of $400 \mathrm{~m}^{2}$ were laid out for plant communities description. In each forest type there were made 37 geobotanical descriptions in the under-crown area, and 10 descriptions in the canopy gaps. 81 descriptions of under- crown areas and 30 descriptions of gaps were made in total. A complete floral list taking into account the layered structure of vegetation was made up for each plot. In each layer, the projective cover of species was defined according to the scale of J. Braun-Blanquet (1964, cited by Mirkin et al., 1989). Latin names of vascular plants and mosses are given according to World Flora Online (2020). Species diversity of communities was evaluated through the indicators of species richness and species saturation (Smirnova et al., 2002).

\subsection{Population-ontogenetic methods and classification of the ecological-coenotic groups of vascular plant}

The periodization of ontogenesis proposed by T.A. Rabotnov (1950) and supplemented by Uranov (1975) and his students (Zaugolnova et al., 1988) is used. The following states are distinguished in the tree ontogenesis: juvenile (j); immature (im); virginal (v); young generative (g1), mature generative (g2) and old generative (g3); senile (s) (Smirnova et. al., 1999; Evstigneev \& Korotkov, 2016). The ontogenetic states of woody plants were determined based on previously published works (Romanovsky, 2001; Evstigneev, 2014; etc.). The composition of tree cenopopulations was determined in under-crown areas and gaps in each forest type. Plots of different sizes were subjected to recording. Immature, virginal, generative and senile trees over $1.5 \mathrm{~m}$ high were counted on 0.25 ha plots (in triplicate for each forest type). Immature and virginal trees up to $1.5 \mathrm{~m}$ high were counted on $100 \mathrm{~m}^{2}$ plots (in 6-fold repetition for each forest type). Juvenile individuals were counted on $1 \mathrm{~m}^{2}$ plots (in 30 -fold repetition for each forest type). The data obtained were extrapolated for 1 ha. The type of ontogenetic spectrum was established according to the classification proposed by T.A. Rabotnov (1950), later supplemented and detailed (Rysin \& Rysina, 1966; Uranov \& Smirnova, 1969; Zaugolnova et al., 1988). In addition to ontogenetic states, the absolute age of trees was determined: core samples were taken with an increment borer near the base of the trunk to calculate the number of annual rings.

The paper is using the classification of the ecologicalcoenotic groups of vascular plant species developed for European Russia (Smirnova et al., 2002, 2004; Smirnova, 2004). The ecological-coenotic structure refers to the composition and quantitative ratio of species belonging to different ecological-coenotic groups. According to Nitcenko (1969) ecological-coenotic groups shall mean the large groups of ecologically close species that are associated with different types of communities in their genesis. All species were divided into the following ecological-coenotic groups: $\mathrm{Br}$ - boreal species, $\mathrm{Md}$ - meadow-forest edge, $\mathrm{Nm}$ - nemoral, $\mathrm{Nt}$ - nitrophilic, $\mathrm{Wt}$ - near-water, others other ECGs (Smirnova et al., 2017). 


\subsection{Soil-zoological methods}

Quantitative calculations of soil invertebrates of the macrofauna size bracket were carried out in gaps and undercrown areas of three forest types. Records in litter and soil were made by excavation and manual analysis of soil samples (Gilyarov, 1975). Invertebrates were fixed in 70$80 \%$ ethanol. The size of a separate sample was $25 \times 25$ $\mathrm{cm}$, the depth up to $30 \mathrm{~cm}$. In aspen-hornbeam forest 54 soil samples were taken in under-crown areas $(18-$ under aspen canopy and 18 - under hornbeam canopy) and 18 samples in the canopy gaps ( 3 gaps examined); in the beech-fir-hornbeam forest 72 soil samples were taken in under-crown areas (18 - under beech canopy, 18 - under fir canopy and 18 - under hornbeam canopy) and 18 samples in the canopy gaps ( 3 gaps examined); in the firbeech forest 54 soil samples were taken in under-crown areas (18 - under fir canopy and 18 under beech canopy) and 18 samples in the canopy gaps (3 gaps examined). Insects, mollusks, crustaceans, and millipedes were identified up to supraspecific taxa (using field guides (Likharev \& Rammelmeyer, 1952; Lokshina, 1969; Mamaev, 1972). Earthworm species were identified with field guides (Vsevolodova-Perel, 1997). The morphoecological groups of earthworms are differ in habitat in different soil horizons and in their functional role in the mineralization of organic residues (Bouche, 1977).

\subsection{Ecological characteristics of forest communities}

Ecological characteristics of communities ( $\mathrm{L}$ - light factor; $\mathrm{R}-\mathrm{pH} ; \mathrm{F}$ - soil moisture; $\mathrm{N}$ - nitrogen content; $\mathrm{T}$ thermal factor; $\mathrm{K}$ - continentality; $\mathrm{H}$ - soil humus) were obtained as weighted average scores for the corresponding species characteristics according to the ecological scale of Landolt (1977). Descriptions were ordinated with the indirect gradient detrended correspondence analysis and determination of the correlation level (r) and significance level (p) (Detrended Correspondence Analysis (DCA) in PC-ORD 5.0, SpeDiv, Past software).

\section{Results}

\subsection{The aspen-hornbeam forest type}

In the under-crown area, the tree stand is dominated by Carpinus betulus and codominated by Populus tremula. Cerasus avium, Fagus orientalis, and Quercus hartwissiana are found as admixture. Canopy closure is $80-90 \%$. Abies nordmanniana, Carpinus betulus, Corylus avellana, and Fagus orientalis are often found in the undergrowth layer, while Betula pubescens, Crataegus monogyna, and Daphne caucasica are found in the admixture together with
Pyrus caucasica and Quercus hartwissiana. The projective cover of the layer is $10-30 \%$. Lonicera caprifolium and Polygonatum glaberrimum dominate the herb-dwarf shrub layer, and Abies nordmanniana, Carex sylvatica, Carpinus betulus, Cerasus avium, Fraxinus excelsior, Hedera helix, Vincetoxicum scandens, etc. are common. The projective cover of the layer ranges from 30 to $70 \%$. The moss layer is distributed sporadically on elevations near the tree trunk and deadwood and is rarely seen on soil mounds; the projective cover is $3-5(10) \%$. Anomodon attenuatus, Brachytheciastrum velutinum, Hypnum cupressiforme, Leucodon sciuroides are the common species in the layer.

Light demanding species dominate the tree stand of the community. Shade-tolerant Abies nordmanniana and $\mathrm{Fa}$ gus orientalis are found as isolated rare trees. The full ontogenetic spectrum (with all ontogenetic groups represented in the ontogenetic spectrum of the species cenopopulation) was recorded for Carpinus betulus cenopopulation. In the aspen-hornbeam forest type, the first generation of hornbeam trees is decaying, and the share of standing dead trees reaches $40 \%$. The invasive type of the ontogenetic spectrum (with only juvenile and immature individuals represented in the spectrum) is typical for the cenopopulations of Acer platanoides, A. campestre, Fagus orientalis, and Fraxinus excelsior. Abies nordmanniana, Populus tremula, Quercus hartwissiana, and Tilia begoniifolia cenopopulations have the intermittent spectrum (with one or more ontogenetic groups missing from the spectrum), whereas Betula pubescens and Cerasus avium (Fig. 3) have fragmented spectrum (with only one or more ontogenetic groups present in the spectrum).

Soil macrofauna in the aspen-hornbeam type of forest in under-crown areas is represented by 19 orders and families. The total number of invertebrates is $127 \mathrm{ind} . / \mathrm{m}^{2}$, and the biomass is $6.27 \mathrm{~g} / \mathrm{m}^{2}$ (Table 1,2). Among trophic groups, saprophages and predators dominate in terms of quantity (Fig. 4), and saprophages in biomass (Table 2). Saprophages make up $83 \%$ of the total macrofauna biomass. The average number of litter and soil forms does not differ significantly (Fig. 5).

Differential consideration of under-crown areas shows that the density of macrofauna is twice as high under aspen crowns $\left(86 \pm 9.8\right.$ ind. $\left./ \mathrm{m}^{2}\right)$ as under hornbeam $(41 \pm 5.5$ ind./ $\mathrm{m}^{2}$ ), while the biomass between the two tree species does not differ $\left(3.17 \pm 1.7\right.$ and $3.10 \pm 2.5 \mathrm{~g} / \mathrm{m}^{2}$ under aspen and hornbeam crowns, respectively) due to the fact that by the summer season, easily decomposable hornbeam litter fall is mostly utilized whereas decomposition-resistant aspen litter fall still remains. Therefore, the number of small litter forms is higher in under-crown areas of aspen than in that of hornbeam. In under-crown areas of aspen the litter horizon is inhabited by representatives of fam. Elateridae, order Lithobiomorpha fam. Pholcidae, fam. Scarabaeidae, fam. Julidae, suborder Oniscidea, the mineral horizon is 

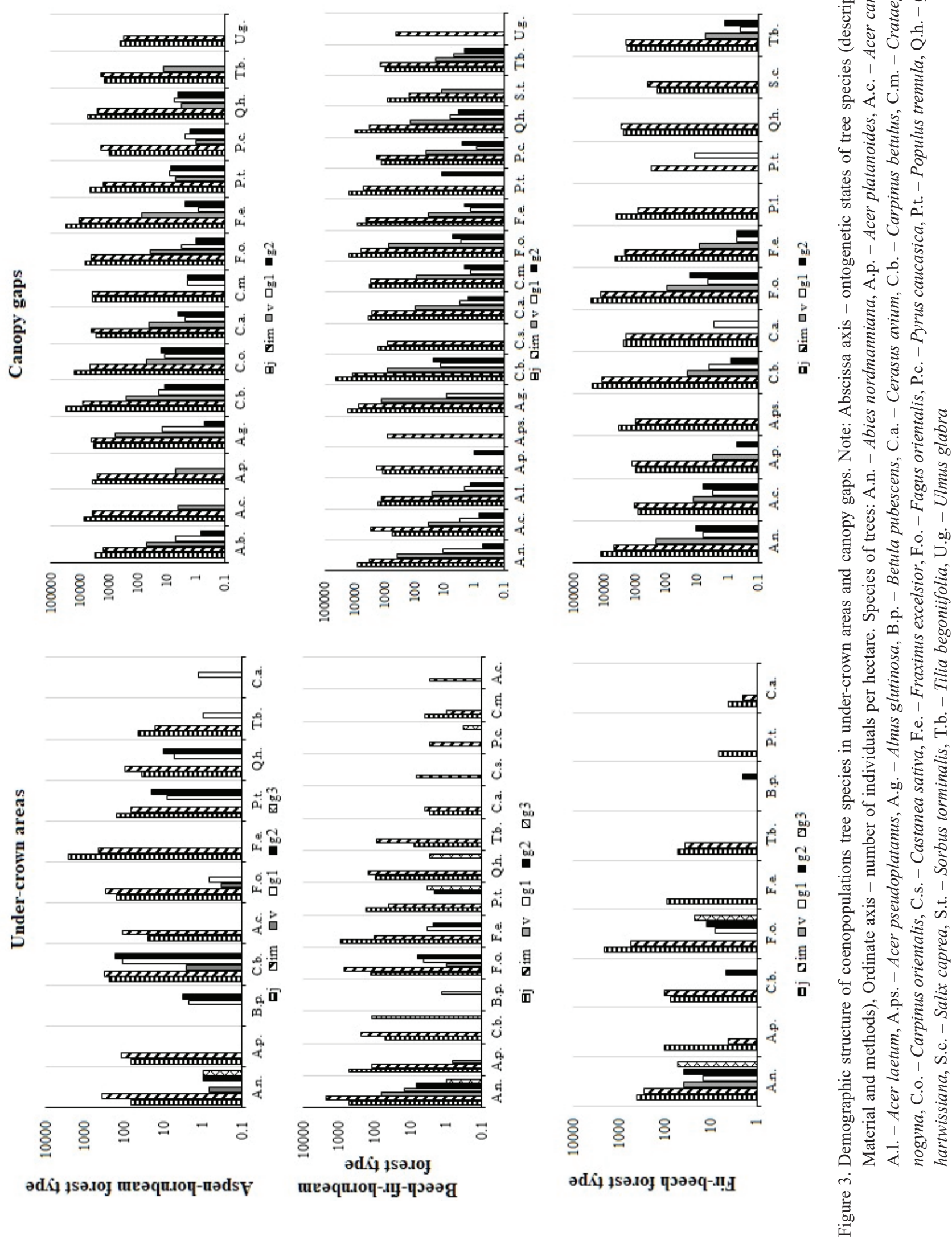
Table 1. The number of macrofauna (ind. $\left./ \mathrm{m}^{2}\right)$ in under-crown areas and canopy gaps

\begin{tabular}{|c|c|c|c|c|c|c|c|}
\hline \multirow{3}{*}{$\begin{array}{l}\text { Taxonomic groups of } \\
\text { invertebrates }\end{array}$} & \multirow{3}{*}{$\begin{array}{l}\text { Trophic } \\
\text { groups }\end{array}$} & \multicolumn{6}{|c|}{ Type of forest } \\
\hline & & \multicolumn{2}{|c|}{ aspen-hornbeam } & \multicolumn{2}{|c|}{ beech-fir-hornbeam } & \multicolumn{2}{|c|}{ fir-beech } \\
\hline & & $\begin{array}{l}\text { under- } \\
\text { crown }\end{array}$ & $\begin{array}{l}\text { canopy } \\
\text { gap }\end{array}$ & $\begin{array}{l}\text { under- } \\
\text { crown }\end{array}$ & $\begin{array}{l}\text { canopy } \\
\text { gap }\end{array}$ & $\begin{array}{l}\text { under- } \\
\text { crown }\end{array}$ & $\begin{array}{c}\text { canopy } \\
\text { gap }\end{array}$ \\
\hline fam. Araneidae & \multirow{10}{*}{ predators } & 0 & 0 & $2 \pm 0.1$ & 0 & 0 & 0 \\
\hline fam. Pholcidae & & $2 \pm 0.1^{*}$ & 0 & $6 \pm 2.3$ & 0 & 0 & 0 \\
\hline order Pseudoscorpionida & & $4 \pm 0.2$ & $4 \pm 2.5$ & $9.6 \pm 3.5$ & 0 & 0 & 0 \\
\hline order Scolopendrida & & $10 \pm 4.5$ & 0 & $1.8 \pm 0.3$ & 0 & $2 \pm 0.1$ & 0 \\
\hline order Geophilomorpha & & $12 \pm 4,5$ & $10 \pm 3.1$ & $9.6 \pm 3.2$ & $14 \pm 4.3$ & $8 \pm 0.8$ & $2 \pm 0.1$ \\
\hline order Lithobiomorpha & & $14 \pm 6.5$ & $14 \pm 6.2$ & $16.8 \pm 3.6$ & $14 \pm 2.4$ & $10 \pm 2.5$ & $10 \pm 1.5$ \\
\hline order Hemiptera & & 0 & 0 & $1 \pm 0.2$ & 0 & 0 & 0 \\
\hline fam. Carabidae & & $1 \pm 0.2$ & $8 \pm 4.5$ & $0.6 \pm 0.1$ & $4 \pm 0.2$ & $1 \pm 0.2$ & $4 \pm 0.4$ \\
\hline fam. Staphylinidae & & $2 \pm 0.1$ & $6 \pm 3.1$ & $3.6 \pm 0.4$ & $2 \pm 0.6$ & 0 & $4 \pm 0.4$ \\
\hline fam. Tenebrionidae & & 0 & $1 \pm 0.2$ & $1.2 \pm 0.2$ & $\mathbf{0}$ & 0 & $2 \pm 0.1$ \\
\hline fam. Chrysomelidae & \multirow{3}{*}{ phytophages } & $1 \pm 0.2$ & $4 \pm 2.4$ & $1.8 \pm 0.2$ & $2 \pm 0.1$ & 0 & 0 \\
\hline fam. Elateridae & & $11 \pm 4.6$ & $18 \pm 6.4$ & $13.2 \pm 4.5$ & $8 \pm 3.5$ & $7 \pm 2.2$ & $4 \pm 2.2$ \\
\hline fam. Scarabaeidae & & $6 \pm 4.3$ & $2 \pm 0.1$ & $1.8 \pm 0.3$ & $2 \pm 0.1$ & $1 \pm 0.2$ & $2 \pm 0.1$ \\
\hline superfam.Cucujoidea & \multirow{3}{*}{ mixophages } & 0 & 0 & 0 & 0 & $1 \pm 0.2$ & 0 \\
\hline fam. Forficulidae & & $5 \pm 2.5$ & $2 \pm 0.1$ & $1.8 \pm 0.2$ & $2 \pm 0.1$ & $1 \pm 0.2$ & $2 \pm 0.1$ \\
\hline order Trichoptera & & 0 & 0 & 0 & 0 & 0 & $2 \pm 0.1$ \\
\hline order Pulmonata & \multirow{9}{*}{ saprophages } & 0 & 0 & 0 & 0 & $1 \pm 0.2$ & 0 \\
\hline fam. Limacidae & & $3 \pm 0.5$ & $2 \pm 0.1$ & $3.6 \pm 0.3$ & $2 \pm 0.1$ & $3 \pm 0.1$ & $2 \pm 0.1$ \\
\hline fam. Lumbricidae & & $18 \pm 4.9$ & $66 \pm 9.5$ & $15 \pm 3.5$ & $44 \pm 3.6$ & $27 \pm 3.5$ & $42 \pm 2.5$ \\
\hline suborder Oniscidea & & $14 \pm 6.5$ & $18 \pm 6.3$ & $15 \pm 4.6$ & $18 \pm 4.5$ & $3 \pm 0.2$ & $2 \pm 0.1$ \\
\hline order Polydesmida & & 0 & 0 & $2 \pm 0.2$ & 0 & $2 \pm 0.1$ & 0 \\
\hline fam. Julidae & & $18 \pm 8.8$ & $26 \pm 4.8$ & $33.6 \pm 5.4$ & $16 \pm 2.8$ & $3 \pm 0.3$ & $2 \pm 0.1$ \\
\hline fam. Ectobiidae (imago) & & $1 \pm 0.2$ & 0 & 0 & 0 & 0 & 0 \\
\hline order Diptera (larvae) & & $1 \pm 0.2$ & $2 \pm 0.1$ & $3.6 \pm 0.4$ & $4 \pm 0.2$ & $3 \pm 0.3$ & 0 \\
\hline fam. Tipulidae (larvae) & & 0 & $4 \pm 0.8$ & 0 & $2 \pm 0.1$ & 0 & 0 \\
\hline fam. Lampyridae (imago) & \multirow{2}{*}{ afagi } & $2 \pm 0.1$ & 0 & $1 \pm 0.2$ & 0 & 0 & $2 \pm 0.1$ \\
\hline order Lepidoptera (cocoons) & & $2 \pm 0.1$ & 0 & 0 & 0 & 0 & 0 \\
\hline \multicolumn{2}{|l|}{ Total number: } & $127 \pm 15.6$ & $193 \pm 22.5$ & $144.6 \pm 31.2$ & $134 \pm 18.6$ & $76 \pm 15.4$ & $80 \pm 19.2$ \\
\hline
\end{tabular}

* bold type points out statistically significant differences between under-crown areas and canopy gaps within a single forest type (Kruskell-Wallis test)

dominated by representatives of the orders Scolopendrida, Geophilomorpha, fam. Lumbricidae and larvae of fam. Elateridae, among the representatives of fam. Lumbricidae only two species of the endogeic group of earthworms were found in the aspen under-crown areas: Aporrectodea jassyensis and Dendrobaena schmidti. In the undercrown areas of hornbeam the litter is inhabited by species of fam. Julidae, larvae of fam. Scarabaeidae and epigeic earthworms (fam. Lumbricidae). Three species of epigeic earthworms - Dendrobaena octaedra, Dendrodrilus rubi- dus tenuis, and Eiseniella tetraedra - were found. In the mineral horizon, representatives of the orders Scolopendrida, Lithobiomorpha, Geophilomorpha and endogeic worms A. jassyensis and D. schmidti are typical.

The canopy gap area in the aspen-hornbeam forest ranges from 290 to $365 \mathrm{~m}^{2}$, each gap is $10-15$ years old. On the periphery of the gaps, Carpinus betulus dominates the stand, Populus tremula is often the codominant; Alnus glutinosa, Fraxinus excelsior, Quercus hartwissiana, Betula pubescens, etc. are rarely found as admixture. The 
Table 2. Biomass of the main trophic groups of macrofauna $\left(\mathrm{g} / \mathrm{m}^{2}\right)$ in under-crown areas and canopy gaps

\begin{tabular}{|l|c|c|c|c|c|c|}
\hline \multirow{2}{*}{ Trophic groups } & \multicolumn{4}{|c|}{ Type of forest } \\
\cline { 2 - 8 } & \multicolumn{2}{|c|}{ aspen-hornbeam } & beech-fir-hornbeam & \multicolumn{3}{c|}{ fir-beech } \\
\cline { 2 - 8 } & under-crown & canopy gap & under-crown & canopy gap & under-crown & canopy gap \\
\hline saprophages & $5.2 \pm 1.4$ & $\mathbf{8 . 8} \pm \mathbf{2 . 2 *}$ & $5.03 \pm 1.2$ & $\mathbf{9 . 6} \pm \mathbf{2 . 4}$ & $9.7 \pm 4.4$ & $\mathbf{2 4 . 5} \pm \mathbf{4 . 8}$ \\
\hline predators & $0.56 \pm 0.05$ & $0.48 \pm 0.1$ & $0.61 \pm 0.3$ & $0.8 \pm 0.5$ & $0.44 \pm 012$ & $0.16 \pm 0.05$ \\
\hline phytophages & $0.37 \pm 0.1$ & $0.3 \pm 0.1$ & $0.34 \pm 01$ & $\mathbf{2 . 0 4} \pm \mathbf{0 . 9}$ & $0.08 \pm 0.06$ & $0.02 \pm 0.01$ \\
\hline mixophages & $0.14 \pm 0.1$ & $0.08 \pm 0.04$ & $0.02 \pm 0.01$ & $0.16 \pm 0.03$ & $0.08 \pm 0.3$ & $0.12 \pm 0.08$ \\
\hline Total biomass: & $6.27 \pm 2.4$ & $9.67 \pm 2.8$ & $6.0 \pm 1.5$ & $\mathbf{1 2 . 6} \pm \mathbf{3 . 7}$ & $10.3 \pm 2.5$ & $\mathbf{2 4 . 8} \pm \mathbf{3 . 8}$ \\
\hline
\end{tabular}

* bold type points statistically significant differences between under-crown areas and canopy gaps within a single forest type (Kruskell-Wallis test).

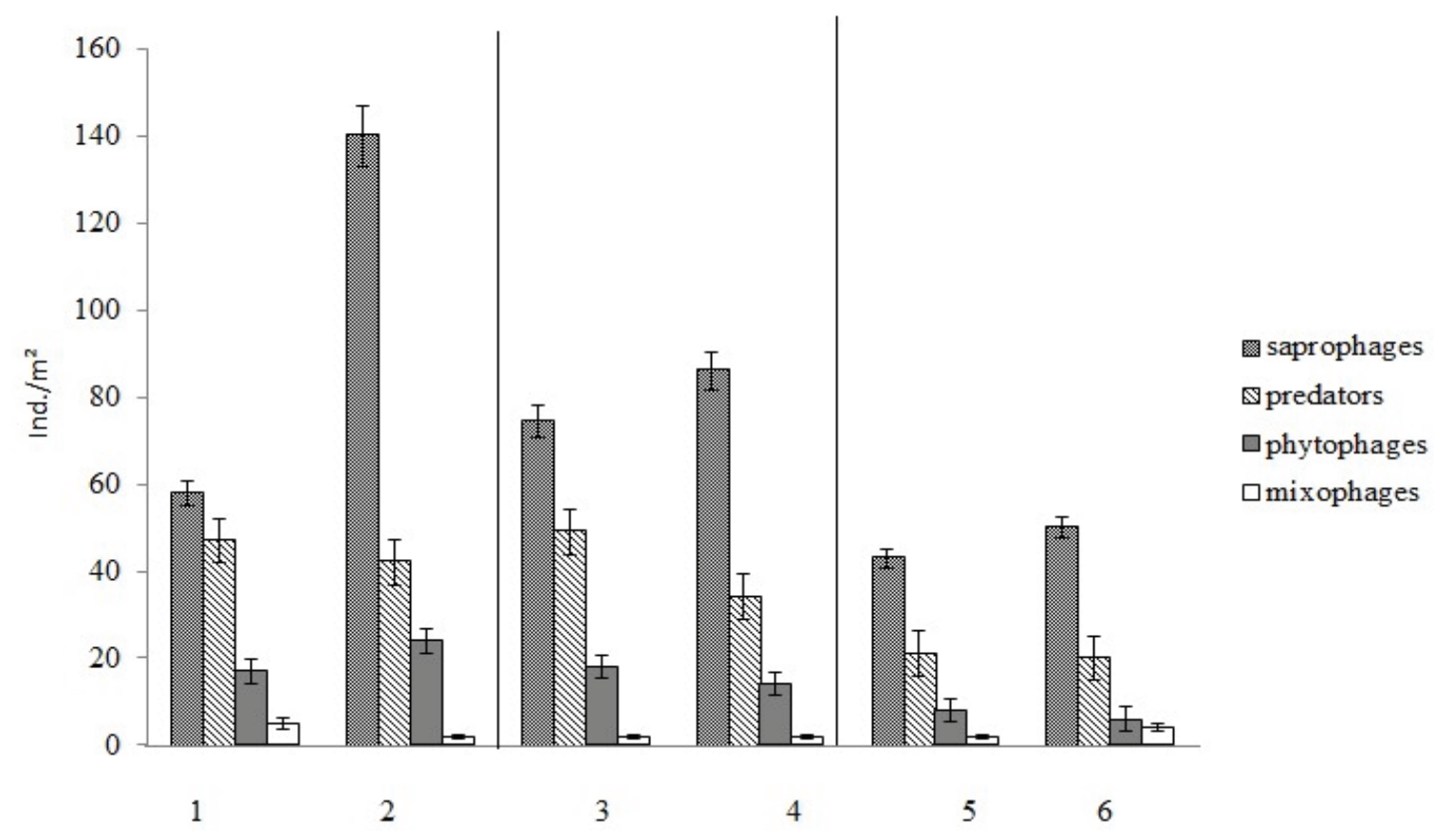

Figure 4. The number of trophic groups of soil macrofauna in under-crown areas $(1,3,5)$ and canopy gaps $(2,4,6)$ of coniferousdeciduous forests of the northwestern Caucasus (1-6 plant community numbers as in Fig. 2)

projective cover of the tree stand layer ranges from 10 to $30 \%$. The undergrowth is well developed, the projective cover ranges from 30 to $80 \%$. The tree stand is dominated by Alnus glutinosa, Carpinus betulus, Corylus avellana, and Abies nordmanniana. The projective cover of the herbdwarf shrub layer ranges from 40 to $100 \%$. Most often, the layer is dominated by Rubus caesius, often the co-dominants are Galeopsis tetrahit, Lonicera caprifolium, Fragaria vesca, Carex sylvatica, Solidago virgaurea and Viola alba subsp. dehnhardtii. The moss layer is well developed and confined to deadwood, mounds, and elevations near tree trunks. The projective cover of the layer ranges from 5 to $40 \%$. Hypnum cupressiforme, Leucodon immersus are common species here.

In the gaps of the aspen-hornbeam type of forest, the full ontogenetic spectrum (due to generative trees along the gap periphery) was found for the cenopopulation of Abies nordmanniana, Alnus glutinosa, Carpinus betulus, C. orientalis, Cerasus avium, Fagus orientalis, Fraxinus excelsior, Populus tremula, Pyrus caucasica, and Quercus hartwissiana. The invasive type was found for Acer campestre, A. platanoides, Tilia begoniifolia and Ulmus glabra, 
the intermittent type - for Crataeus monogyna (Fig. 3). Thus, in the gaps of young post-logging forests, both light demanding and shade-tolerant tree species are being successfully regenerating.

Representatives of 16 taxonomic groups of macrofauna (orders and families) were found in the gaps of aspenhornbeam forests. The total number (Table 1) and biomass (Fig. 6) of gap macrofauna are significantly higher than that of under-crown areas. At the same time, the number (Fig. 4) and biomass (Table 2) of predators, phytophages and mixophages in under-crown areas and gaps do not differ. Significant differences were found for the trophic group of saprophages - their number is almost 3 times higher, and biomass is 1.7 times higher in gaps as compared to under-crown areas. Unlike the under-crown areas the biomass of soil-dwelling invertebrates (Fig. 7) is high in gaps, particularly due to the presence of large earthworms, including the anecic form. The litter horizon is dominated by saprophages of the fam. Julidae and suborder Oniscidea as well as epigeic earthworms $D$. attemsi and D. octaedra. Single representatives of other groups and families are found. In mineral horizons, predators of order Geophilomorpha; saprophages: Diptera larvae and earthworms - endogeic species $A$. jassyensis and D. schmidti as well as a large anecic species $D$. mariupoliensis are common.

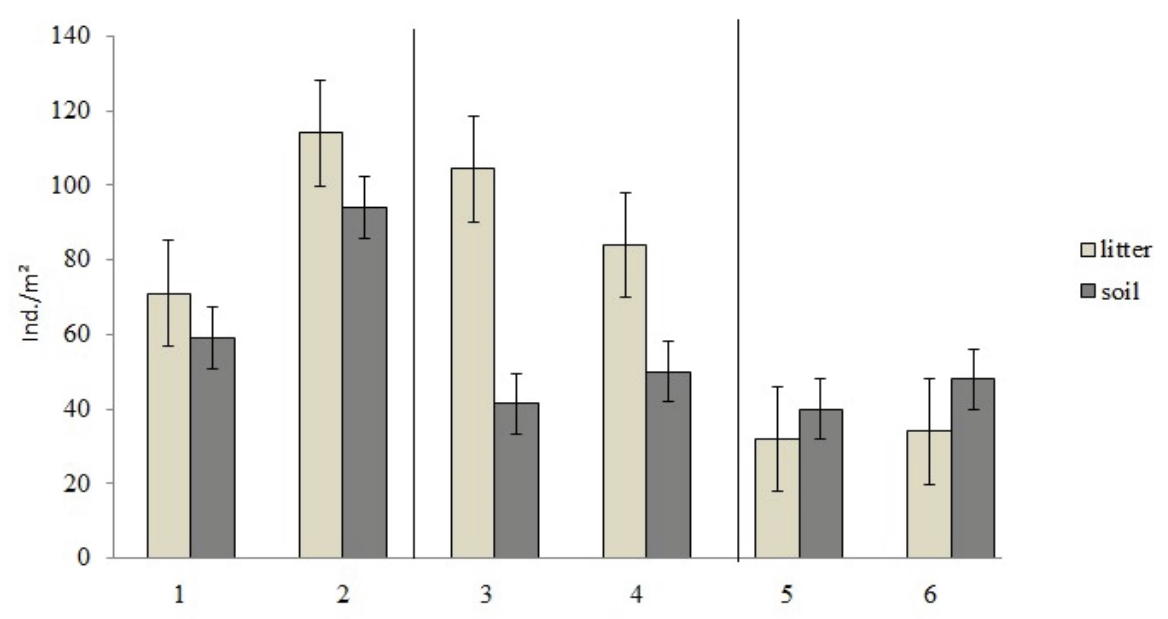

Figure 5. Average number of macrofauna in under-crown areas $(1,3,5)$ and canopy gaps $(2,4,6)$ of coniferous-deciduous forests of the northwestern Caucasus (1-6 plant community numbers as in Fig. 2)

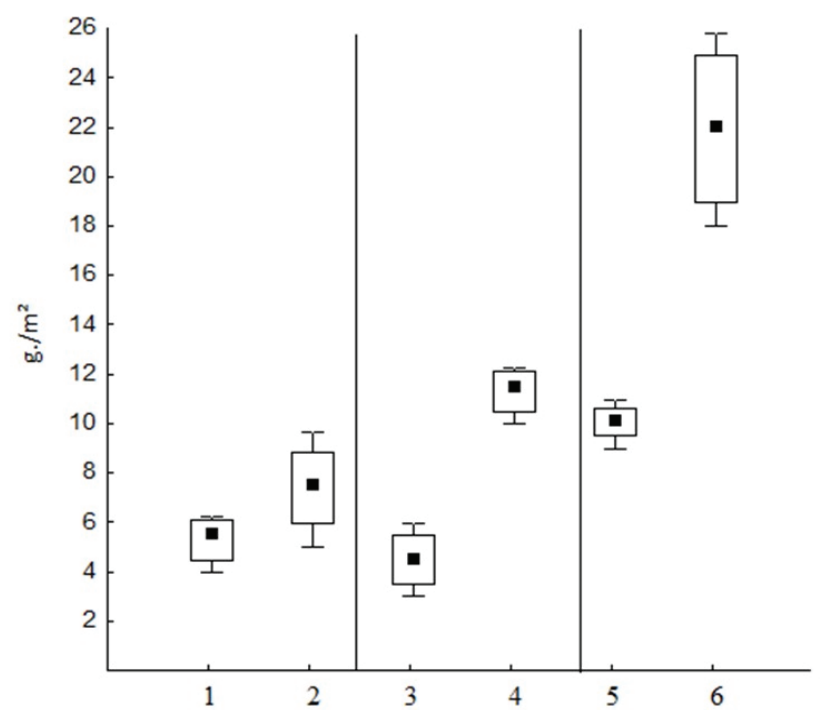

Figure 6. Total biomass of macrofauna in under-crown areas $(1,3,5)$ and canopy gaps $(2,4,6)$ of coniferous-deciduous forests of the northwestern Caucasus (1-6 plant community numbers as in Fig. 2) 


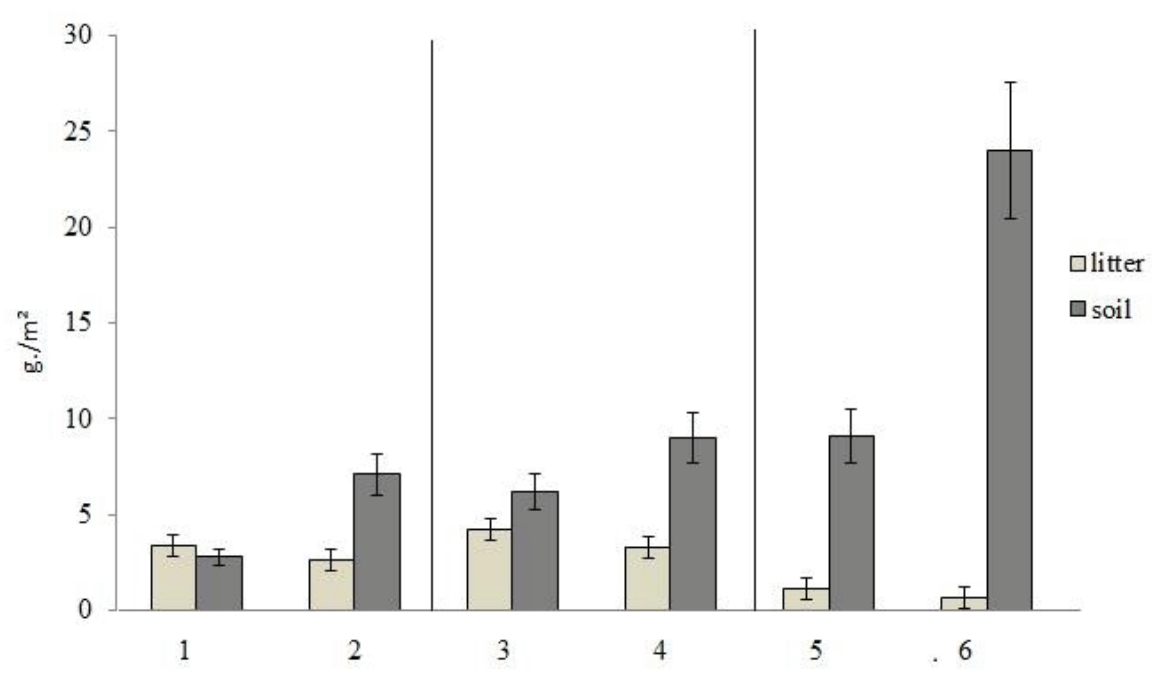

Figure 7. Average biomass of macrofauna in the soil and in the litter of under-crown areas $(1,3,5)$ and canopy gaps $(2,4,6)$ of coniferous-deciduous forests of the northwestern Caucasus (1-6 plant community numbers as in Fig. 2)

\subsection{Beech-fir-hornbeam type of forest}

In the under-crown area, the composition of the stand is codominated by Carpinus betulus, Fagus orientalis and Abies nordmanniana. Tilia begoniifolia is found in the admixture. The projective cover of the layer ranges from 70 to $90 \%$. The undergrowth is dominated by Abies nordmanniana (im, v) with the density 3-4, less frequently by Fagus orientalis - 1-2 and Rhododendron luteum (1). The projective cover of the layer ranges from 30 to $80 \%$. There are no dominants of the herb-dwarf shrub layer. Common species are Abies nordmanniana, Carex sylvatica, Dryopteris filix-mas, Euonymus europaea, Lonicera caprifolium, Polygonatum glaberrimum, Rubus caesius, Solidago virgaurea, Dioscorea communis; the projective coverage of the layer ranges from 20 to $60 \%$. The moss layer is localized on elevations near tree trunks, on tree trunks, deadwood, and stumps. Anomodon attenuatus, Hypnum cupressiforme, Leucodon sciuroides are common species.

In the under-crown areas of the fir-beech-hornbeam forest type, the full ontogenetic spectrum was observed for the cenopopulations of Abies nordmanniana and $\mathrm{Fa}$ gus orientalis. The intermittent spectrum was identified for the cenopopulations of Carpinus betulus, Fraxinus excelsior, Populus tremula, and Quercus petraea; invasive spectrum - for Acer platanoides, Cerasus avium, Tilia begoniifolia, and Crataegus monogyna. The fragmentary type of spectrum represented only by juvenile and immature individuals is typical for light demanding species, i.e. Betula pubescens, Castanea sativa, Pyrus caucasica, and Acer campestre (Fig. 3). Undergrowth of these species was found only in well-lit areas.
The soil macrofauna of the fir-beech-hornbeam type of forest includes representatives of 21 taxa (orders and families) totally amounting to $144 \mathrm{ind} . / \mathrm{m}^{2}$ in terms of numbers (Table 1) and to $6 \mathrm{~g} / \mathrm{m}^{2}$ in terms of biomass (Table 2) were identified in the under-crown areas. Saprophages clearly dominate among trophic groups both in number and in biomass, followed by predators, phytophages, and mixophages (Table 2), as in other types of forest. It is in this type of forest that differences between the number of litter and soil fauna are the greatest; litter is 2.7 times more densely inhabited than soil (Fig. 5) due to the fact that there is a thick mixed litter of decomposition-resistant fir and beech litter, while quickly decomposable hornbeam litter is a favourable trophic resource for litter fauna. Differential consideration of the distribution of invertebrates shows that the highest numbers and biomass of macrofauna were found under fir $\left(59 \pm 6.8\right.$ ind.$/ \mathrm{m}^{2}$ and $\left.2 \pm 0.6 \mathrm{~g} / \mathrm{m}^{2}\right)$ and hornbeam crowns $\left(51 \pm 7.2\right.$ ind.$/ \mathrm{m}^{2}$ and $\left.2.6 \pm 0.7 \mathrm{~g} / \mathrm{m}^{2}\right)$, whereas the lowest - under beech crowns $\left(34 \pm 6.5\right.$ ind.$/ \mathrm{m}^{2}$ and $\left.1.4 \pm 0.5 \mathrm{~g} / \mathrm{m}^{2}\right)$. In under-crown areas of fir, the litter is dominated by calciphilous groups: millipedes of fam. Julidae, order Polydesmida, woodlice (suborder Oniscidea). Geophila predators are typical (order Geophilomorpha) as well as drupes (order Lithobiomorpha) and saprophages earthworms, among which D. schmidti dominates are typical for humus and mineral horizons. The under-crown areas of hornbeam show the greatest variety of litter and soil macrofauna. Representatives of Lithobiomorpha, Pseudoscorpionida orders, and fam. Pholcidae and Staphylinidae as well as epigeic species of fam. Lumbricidae $D$. hortensis are typical for the litter. In the soil, the larvae of snapping beetles (fam. Elateridae) and dipterans (subor- 
der Diptera) are numerous, as well as predatory centipedes of Scolopendrida order and earthworms, among which $D$. schmidti dominates; also, a single anecic species $D$. mariupoliensis was found. Under the beech crowns, millipedes, woodlice and drupes dominate in the litter; in the soil, geophiles, larvae of snapping beetles, and earthworms are few in number - singular individuals of endogeic species D. schmidti and A. jassyensis are found in soil.

The area of canopy gaps ranges from 240 to $340 \mathrm{~m}^{2}$. The gaps are 10 to 15 years old. The stand of gaps peripheryis dominated by Carpinus betulus, Fagus orientalis, whereas Abies nordmanniana is found as admixture. Populus tremula, Quercus hartwissiana, Acer platanoides, and Alnus glutinosa are rare. The projective cover of the stand layer ranges from 10 to $30 \%$. The undergrowth is often dominated by Rhododendron luteum. Abies nordmanniana, Corylus avellana, Crataegus microphylla, etc are common species here. The projective cover of the layer varies greatly from 40 to $80 \%$. The herb-dwarf shrub layer is well developed, the projective cover is 60 to $100 \%$. The layer is dominated by Rubus caesius, Carex sylvatica, Dioscorea communis, Lonicera caprifolium, Rhododendron luteum, Galeopsis tetrahit, Lactuca muralis, Myosotis amoena, etc. Common moss species are Anomodon attenuatus, Atrichum undulatum, Leucodon sciuroides, Plagiomnium medium, etc. The projective cover of the moss layer varies from 3 to $25 \%$. Mosses are confined to dead wood, elevations near the tree trunk, mounds and stumps.

In the canopy gaps of the beech-fir-hornbeam forests, the full ontogenetic spectrum was observed for the cenopopulations of Abies nordmanniana, Acer campestre, A. laetum, Carpinus betulus, Cerasus avium, Crataegus monogyna, Fagus orientalis, Fraxinus excelsior, Pyrus caucasica, Quercus hartwissiana, and Tilia begoniifolia. The invasive type of spectrum was found for Alnus glutinosa, Castanea sativa, and Sorbus torminalis. The intermittent spectrum - for Acer platanoides and Populus tremula, fragmented - for Acer pseudoplatanus, Populus tremula and Ulmus glabra (Fig. 2). Thus, the beech-fir-hornbeam type of forest enjoys the regeneration of the largest number of tree species in comparison with other types of forest.

The macrofauna of the beech-fir-hornbeam forest gaps includes 14 taxa (orders and families), while the total number does not differ significantly from the number in the under-crown areas (Table 1), and the biomass is 2 times higher as compared to the under-crown areas (Table 2). The biomass of all trophic groups of invertebrates, i. e. saprophages, predators, phytophages, and mixophages is significantly higher in gaps (Table 2). The number of litter dwellers is higher than that of soil (Fig. 5), while the population of soil on the contrary exceeds that of litter in terms of biomass (Fig. 7). Saprophages such as woodlice, gastropods, millipedes, and epigeic earthworms are numerous in litter. Predators are less common and are mostly rep- resented by rove beetles and ground beetles. Among phytophages, imagines of leaf beetles and larvae of lamellicorn beetles are found. Soil is mostly inhabited by saprophages, among which earthworms are predominant: endogeic species D. schmidti and A. jassyensis and anecic species D. mariupoliensis are numerous. Millipedes, fly larvae, and larvae of crane flies (fam. Tipulidae) were also seen which were not found in under-crown areas.

\subsection{Fir-beech forest type}

In the under-crown areas, the stand is only codominated by Fagus orientalis and Abies nordmanniana. Acer platanoides and Carpinus betulus are found as admixtures. The upper sub-layer of the stand is represented exclusively by Fagus orientalis, while the lower one is represented by Abies nordmanniana with a small admixture of Fagus orientalis. The projective cover of the stand is $90-95 \%$. The undergrowth layer is dominated by Abies nordmanniana and Fagus orientalis. Ribes petraeum, Ilex colchica, and Rhododendron ponticum are found as singular trees. The projective cover of the layer ranges from 5 to $20 \%$. The herb-dwarf shrub layer is a dead-soil layer, the projective cover is $5-7 \%$. Common species are Abies nordmanniana, Acer platanoides, and Fagus orientalis. Singular plants of Cephalanthera rubra, Dryopteris filix-mas, Fraxinus excelsior, Moehringia trinervia, Monotropa hypopitys, Neottia nidus-avis and Tilia begoniifolia are found. The moss layer is localized on elevations near tree trunks, on tree trunks, deadwood, and soil. The projective cover is $5-10(12) \%$. Common species are Isothecium alopecuroides, Neckera complanata, Eurhynchium angustirete, Hypnum cupressiforme, Leucodon sciuroides and Ulota crispa.

Only the cenopopulation of Abies nordmanniana has the full ontogenetic spectrum in the under-crown area of the fir-beech forest. The cenopopulation of Fagus orientalis has an intermittent spectrum with no virginal individuals. The intermittent spectrum was also observed for the Carpinus betulus cenopopulation. Plants of this species with reduced vitality are found very rarely on the area of former gaps. Due to the high growth rate, hornbeam quickly occupies vacant areas. The invasive type is observed in Acer platanoides and Tilia begoniifolia, cenopopulations of Fraxinus excelsior, Betula pubescens, Cerasus avium, and Populus tremula have the fragmentary type of spectrum (Fig. 2). The undergrowth of the above species dies early due to the lack of light.

The composition of macrofauna in the fir-beech forest type is characterized by the smallest variety of taxonomic groups, and the smallest number (Table 1), but the biomass of macrofauna in this forest type is significantly higher than in other forest types (Fig. 6; Table 2). Representatives of 15 families and orders were found in the under-crown areas (Table 1). Among trophic groups, sap- 
rophages predominate (Fig. 4; Table 2), which account for more than half of the total population, and their biomass is $94 \%$ of the total biomass. The number and biomass of inhabitants of soil horizons is higher than that of the litter horizon (Fig. 5). The number and biomass of invertebrates in the under-crown areas of fir is significantly higher $\left(44 \pm 8.2\right.$ ind.$\left./ \mathrm{m}^{2} ; 5.9 \pm 1.5 \mathrm{~g} / \mathrm{m}^{2}\right)$ than under beech crowns ( $32 \pm 8.8$ ind. $\mathrm{m}^{2}$ and $4.6 \pm 1.4 \mathrm{~g} / \mathrm{m}^{2}$ ). Larvae and imagines of snapping beetles, millipedes, woodlice, and earwigs are typical inhabitants of fir under-crown areas in litter (fam. Forficulidae); in soil there are predatory millipedes (order Scolopendrida, Lithobiomorpha, Geophilomorpha) and earthworms (D. schmidti and D. mariupoliensis). In the under-crown areas of beech, imagines of snapping beetles (Agriotes sputator) and drupes (Lithobiomorpha) are numerous in litter, whereas earthworms (D. schmidti and D. mariupoliensis) are found in soil.

Canopy gaps are formed as a result of the natural death of old Fagus orientalis trees in the upper sub-layer (trees 40-60 meters high). $80 \%$ of gaps in the fir-beech type of forest were formed as a result of breakage of old beech trees trunks at a height of more than 1 meter, rather than of treefall. During the fall of old trees of the upper sublayer, Fagus orientalis and Abies nordmanniana trees of the lower sub-layer are usually the ones that tend to break. The size of gaps in old-aged fir-beech forests ranges from 320 to $380 \mathrm{~m}^{2}$. Gaps are 10 to 20 years old.

Abies nordmanniana and Fagus orientalis codominate along the periphery of gaps in the tree stand. Earlygenerative Carpinus betulus and Fraxinus excelsior trees are rarely found as admixture. The projective cover of the layer is $5-15 \%$. The undergrowth is dominated by young Fagus orientalis and Abies nordmanniana. The admixture contains Carpinus betulus, Cerasus avium, Sambucus herbacea, S. nigra, Tilia begoniifolia, Fraxinus excelsior and Philadelphus copronarius. The projective cover of the layer is $30-60 \%$. The herb-dwarf shrub layer is unevenly developed, the projective cover ranges from 20 to $100 \%$. Abies nordmanniana, Acer platanoides, Athyrium filix-femina, Carpinus betulus, Circaea lutetiana, Dryopteris filix-mas, Fagus orientalis, Fragaria vesca, Fraxinus excelsior, Prunus laurocerasus, Rubus caesius, Tilia begoniifolia, and Viola mirabilis are common. Rubus caesius and the undergrowth of Abies nordmanniana, Acer platanoides, Carpinus betulus, Fagus orientalis etc. often dominate. Moss is developed sporadically on elevations near tree trunks, on deadwood and mounds. Brachythecium rutabulum, Eurhynchium angustirete, Hypnum cupressiforme, Isothecium alopecuroides, Leucodon sciuroides, Neckera complanata, Pterigynandrum filiforme, Ulota crispa are common.

Cenopopulations of Abies nordmanniana, Acer campester, Carpinus betulus, Fagus orientalis, Fraxinus excelsior, and Tilia begoniifolia have the full ontogenetic spectrum in the gaps of fir-beech forest. The invasive type of spectrum was described for Acer pseudoplatanus, Quercus hartwissiana, Prunus laurocerasus, and Salix caprea; the intermittent type - for Acer platanoides, Cerasus avium and fragmented - for Populus tremula (Fig. 2). Thus, at a late stage, successful restoration of gaps is due to shadetolerant tree species.

The macrofauna in the gaps of the beech-fir type includes 14 taxa (orders and families). The total number does not differ significantly from the under-crown areas (Table 1), but the biomass is 2.5 times higher in comparison with the under-crown areas due to the biomass of soil saprophages (Table 2). Invertebrate biomass in soil is 20 times higher than in litter (Fig. 7), which is due to the high density of earthworms of not only endogeic forms (D. schmidti) but also of large anecic earthworms (D. mariupoliensis). The density of predators, phytophages and mixophages is low (Table 2). The most common soil predators are drupes (order Lithobiomorpha), other representatives are few. It is however interesting that water-loving invertebrates: not only earthworms, mollusks, larvae of dipterans, but also larvae of caddisflies (order Trichoptera) inhabit this area, which serves as an indicator of high soil moisture in the studied forest gaps.

\section{Discussion}

In the studied types of coniferous-deciduous forests of the northwestern Caucasus, the regeneration of tree cenopopulations is much more effective in gaps as compared to under-crown areas. In aspen-hornbeam forests, in undercrown areas the regeneration of 11 tree species was recorded, of which cenopopulations of only 2 species had full ontogenetic spectra with a steady cycle of generations, in the gaps there were 15 species, of which 10 species had full ontogenetic spectra; in the beech-fir-hornbeam forests, in under-crown areas the regeneration of 14 tree species was recorded, with the full ontogenetic spectrum of cenopopulations of only two species, whereas in gaps there were 18 tree species, of which 11 tree species had full ontogenetic spectrum; in old-aged fir-beech forests, in under-crown areas the regeneration of 9 tree species was recorded, of which only cenopopulations of Abies nordmanniana had a steady cycle of generations, in the gaps there were 12 species, with the full ontogenetic spectrum of the populations of 6 tree species (Fig. 2). It is important to note that in all the studied types of coniferous-deciduous forests of the northwestern Caucasus, gaps are not only the place of successful regeneration of a much larger number of tree species cenopopulations, but also the density of tree undergrowth of different species in the gaps is more than 10 times higher than in under-crown areas. The significant role of gaps in the successful regeneration of tree species was noted in oak-pine forests in the United States (Schu- 
mann et al., 2003), beech-dominated forests in Denmark (Ritter et al., 2005), beech forests of Iran (Haghverdi et al., 2012), tropical forests of Costa Rica, where experimental felling with the creation of gaps resulted in successful development of undergrowth, especially that of light demanding species (Dupuy \& Chardon, 2008).

As can be seen from the graph (Fig. 8), the highest species density of vascular plants (the number of species per $400 \mathrm{~m}^{2}$ ) in the under-crown areas of the studied forest types is found for the aspen-hornbeam and beech-fir-hornbeam forest, the lowest - for old-aged fir-beech forests. Low species density of the latter is due to high closure of the tree canopy and, as a result, almost complete absence of ground cover. In the fir-beech type of forest, the height of the tree canopy reaches $60 \mathrm{~m}$. The tree stand is represented by two distinct sub-layers: the lower one is $20-30 \mathrm{~m}$ and the upper one is 50-60 m high. The upper sub-layer is formed by Fagus orientalis, and the lower one - by Abies nordmanniana, which leads to strong shading and the formation of dead-soil communities. In the aspen-hornbeam and beech-fir-hornbeam types of forest, due to the decay of the first generation of tree species, the community is well lit, so there are more favourable conditions for the settlement of light demanding flora of vascular plants, mosses and liverworts.

In the gaps of all types of forest, species density is almost two or more times higher than in under-crown communities, which is explained by good light factor and high soil moisture, as the stand does not intercept precipitation.
These two factors are usually listed as determining a significant increase in the species richness of plants in gaps in comparison with under-crown areas (Denslow \& Spies, 1990). Previous studies showed conclusively that species density of plants is positively correlated with the size of the gap, which determines the amount of light in the first place (Schumann et al., 2003; Ritter et al., 2005; Haghverdi et al., 2012). Our research has shown that not only the size of the gap but also the height of the stand on the periphery of the gaps determines the species density of plants: in the gaps of old-aged fir-beech forests, species density is significantly lower as compared to the gaps of aspen-hornbeam and beech-fir-hornbeam forests due to the high height of the tree canopy (up to 50-60 m) along the periphery of the gaps in fir-beech forests, which creates strong lateral shading and diasporic isolation.

The diagram (Fig. 9) shows vectors of environmental factors whose length and direction reflect the degree of correlation of factors with axes but are not regression lines in the strict sense. The highest correlation with the first DCA axis $(\mathrm{p}<0.005)$ is shown by the indicators of light factor $(\mathrm{r}=-0.96)$, continentality $(\mathrm{r}=-0.87)$, soil humus content $(\mathrm{r}=0.64)$, soil $\mathrm{pH}(\mathrm{r}=-0.63)$, and thermal factor $(\mathrm{r}=-0.58)$. There is no significant strong correlation with the second axis. Only soil nitrogen content showed correlation with the third axis $(\mathrm{r}=0.55)$.

Results of the multi-dimensional analysis of geobotanical descriptions of communities of under-crown areas and gaps in dominant forest types on the ecological scale of

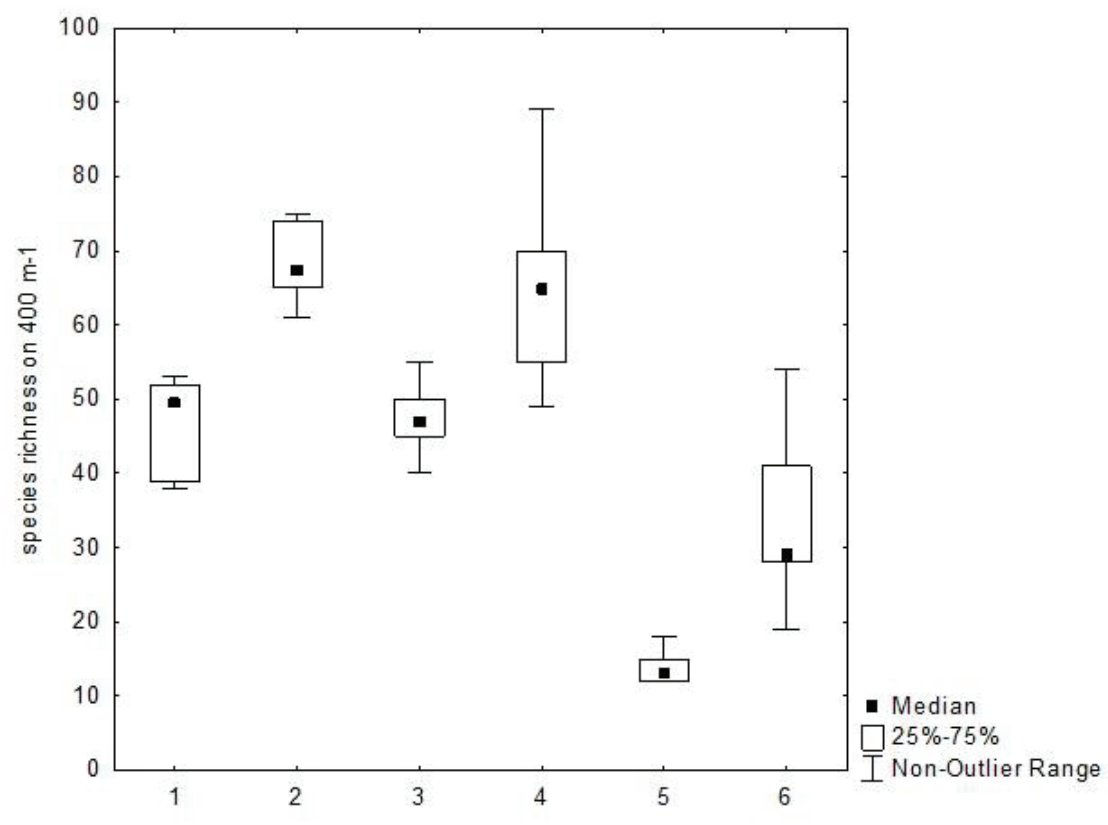

Figure 8. Plant species richness in under-crown areas $(1,3,5)$ and canopy gaps $(2,4,6)$ of coniferous-deciduous forests of the northwestern Caucasus (1-6 plant community numbers as in Fig. 2) 
Landolt (1977) clearly showed that aspen-hornbeam and beech-fir-hornbeam forests have the highest similarity in the under-crown area and gaps: they have a higher proportion of light demanding, heat-loving species that prefer a more neutral and nitrogen-rich soil compared to communities of fir-beech forests. At the same time, in the undercrown area and gaps of fir-beech forests, the share of light demanding species is low whereas the share of plant species that prefer soil with high humus and moisture content is higher, which is also noted for moisture-loving groups of invertebrates.

The ecological-coenotic structure of all dominant types of coniferous-deciduous forests of the northwestern Caucasus in under-crown area and gaps in terms of the number of species is clearly dominated by nemoral species (50 to $80 \%$ of all species), forming the core of the local flora. Boreal species (from 8 to $25 \%$ ) are in second place in terms of species number in the under-crown area, whereas in gaps it is the meadow-forest edge species (from 12 to 25\%) and nitrophilic species (from 5 to 11\%). The share of other groups is insignificant (Fig. 10).

It is important to note that only gap communities in all types of forest include the group of near-water plant spe- cies. This is due to the fact that the ground cover in the gaps receives more moisture from precipitation than that under the canopy, where precipitation is intercepted by tree crowns. In the gaps, large puddles are often formed and remain for a long time, leading to hydrogenic conditions. For example, in the composition of the flora in gaps, such near-water species as Alisma plantago-aquatica, Juncus effusus, Cardamine tenera, Galeopsis tetrahit, Ranunculus repens, etc. are common. And in the composition of the soil macrofauna, even larvae of caddisflies (order Trichoptera) are found.

Due to the fact that soil moisture supply is the most important factor for the functioning of soil invertebrates, especially water-loving saprophages, in the gaps of all types of forest, the saprophage biomass is significantly higher than in under-crown areas. This is most pronounced in oldaged fir-beech forests where much of the precipitation is intercepted by tree crowns. Studies of the influence of tree gaps on the distribution of earthworms in the beech forests of Iran (Kooch \& Hosseini, 2010; Kooch \& Haghverdi, 2014) show that the density and biomass of earthworms decreases as the gaps size increases, and often, the density of earthworms may be higher under the tree canopy, which

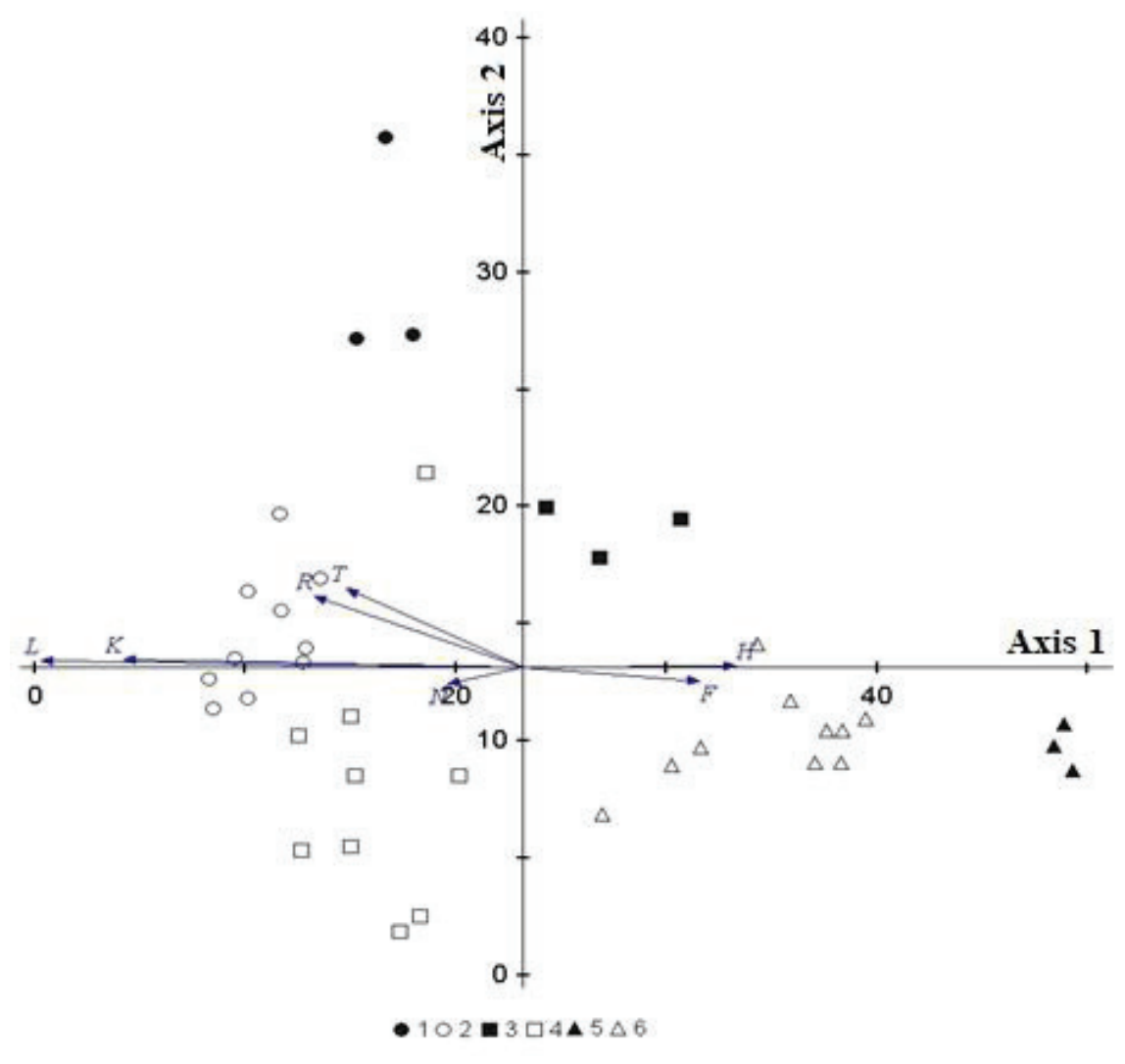

Figure 9. The position of the geobotanical descriptions of the studied communities in the first two axes of DCA together with the vectors of environmental factors (in ecological scale of Landolt (1977); 1-6 plant community numbers as in Fig. 2) 
is explain by the authors by faster drying of the soil in open spaces as compared to the closed ones. In our research, the opposite patterns were seen. This is most likely due to the fact that in the climate of Iran, most of the precipitation falls from September to November (Kooch \& Haghverdi, 2014), while the total amount of precipitation during the year is 1.7 times lower (720 $\mathrm{mm}$ annual rainfall) than in the forests under our research and, moreover, summers are often dry. In the forests of the northwestern Caucasus we studied, the maximum precipitation falls from May to July during the optimal temperature for the soil fauna activity; there are no sharp fluctuations between the seasons and the total amount of precipitation is at least $1.200 \mathrm{~mm}$ of annual rainfall. This uniform humidification creates more favourable conditions for moisture-loving groups of flora and fauna in the gaps as compared to closed under-crown areas.

In the under-crown area, the largest number of ecological-coenotic groups of plants (Fig. 10) was found in beechfir-hornbeam forests (all 6 selected groups). As mentioned above, in these forests, the first post-harvest generation of trees disintegrates and the ground cover lightens, accompanied by an increase in species richness. In the undercrown area of fir-beech forests, on the contrary, a marked decline in the number of ecological-coenotic groups (up to $2-$ nemoral and boreal species) is found that is connected with a strong shading of ground vegetation by trees canopy and formation of dead-soil oligodominant communities. It should be noted that the gaps of all dominant forest types have the maximum number of ecological-coenotic groups of plants (all 6 groups), which is an important feature of gap plant communities as compared to the communities of the under-crown area.

Taxonomic diversity of soil macrofauna in under-crown areas and floristic richness are highest in aspen-hornbeam and beech-fir-hornbeam forests and lowest in fir-beech forests. It is known that the more diverse is the forest stand composition, the higher is the taxonomic and functional diversity of the soil fauna (Cesarz et al., 2007; Sariyildiz \& Küçük, 2008). The composition of litter determines not only trophic conditions for invertebrates (high content of available nutrients, biogenic elements, low acidity, etc.), but also topical conditions: slowly decomposing litter serves as a favourable habitat for the litter fauna, therefore mixed litter of the litter fall of different quality in beechfir-hornbeam forests is more favourable for a larger number of invertebrates. However, in gaps, in contrast to the floristic diversity of all forest types, the taxonomic diversity of macrofauna is reduced; functional diversity, however, is preserved: all the main trophic groups of macrosaprophages are present in gaps, and gaps are an important

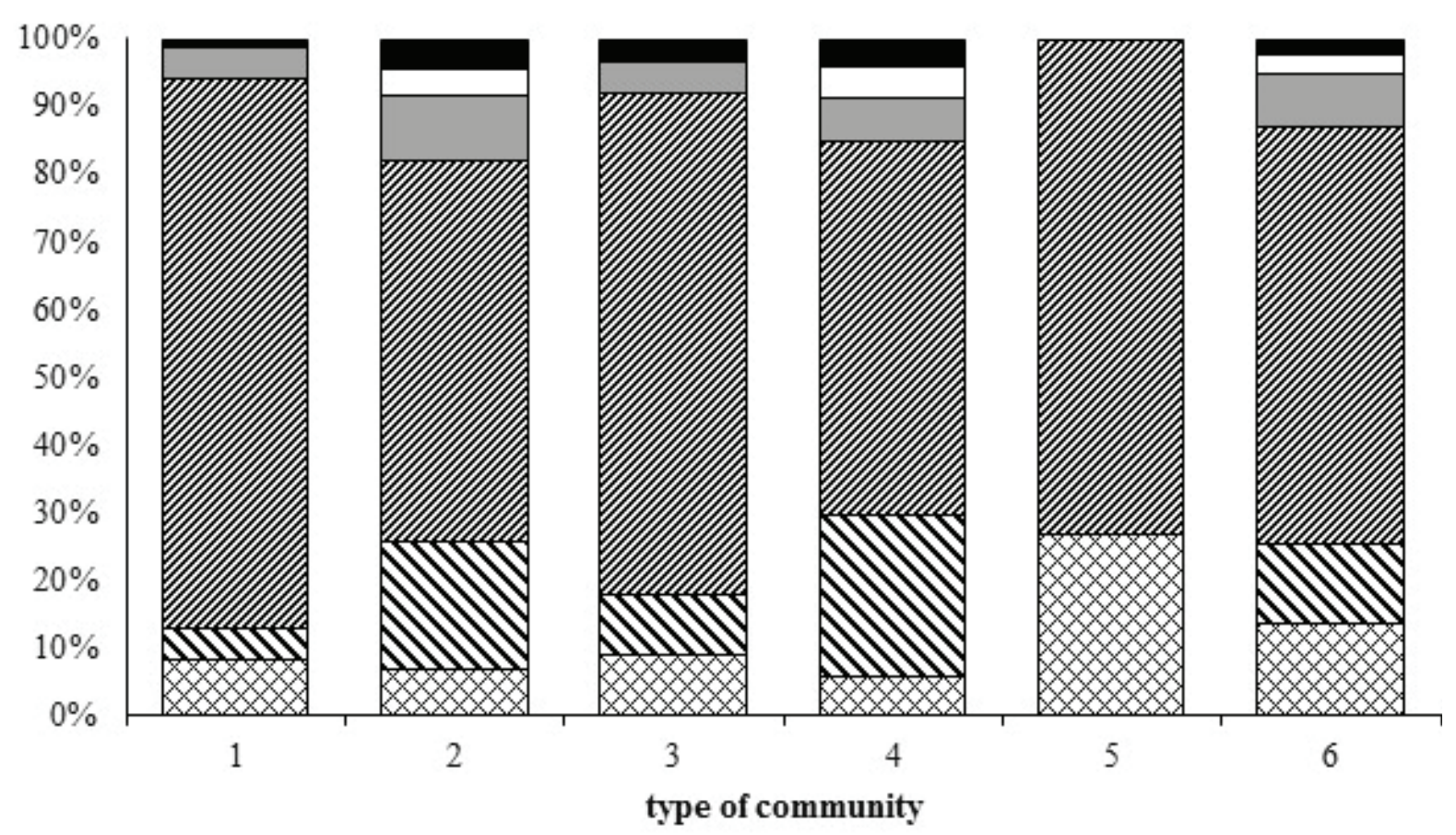

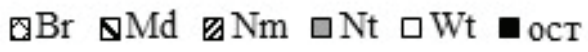

Figure 10. The ratio of eco-cenotic groups of plants of different forest types in under-crown areas $(1,3,5)$ and canopy gaps $(2,4,6)$. Note: 1-6 plant community numbers as in Fig. 2. 
element of the forest mosaic which are in the first place important for the functioning of large soil saprophages earthworms, which process the plant litter. Only gaps have a high biomass of anecic earthworms which are important ecosystem engineers (Lavelle et al., 1997; Eisenhauer et al., 2008; Kooch \& Jalilvand, 2008) and are rarely found in forest communities, being represented usually only in old-aged virgin forests (Geraskina, 2019).

\section{Conclusions}

Thus, it has been found that in the canopy gaps of the studied types of coniferous-deciduous forests of the northwestern Caucasus, the species density of plants is almost two or more times higher than that in the under-crown area due to good light factor and high soil moisture, since the stand does not intercept the rainfall. Regeneration of tree cenopopulations in all types of forest is much more effective in canopy gaps compared to under-crown areas. The density of undergrowth of different types of trees in the canopy gaps is more than 10 times higher than that in the under-crown areas. The maximum number of ecological-coenotic groups of plants is marked in the canopy gaps of all types of forest. All major trophic groups of macrofauna live in the canopy gaps as well as in under-crown areas, but their biomass in gaps is significantly higher than in under-crown areas. Due to the fact that soil moisture supply is also an important factor for the functioning of macrofauna, especially water-loving saprophages, the average saprophages biomass in gaps of all types of forest is 2 times higher than in under-crown areas. Only the gaps have a high biomass of anecic earthworms, which are rarely found in forest communities, and contribute greatly to the transformation of plant litter.

\section{Acknowledgement}

The scientific materials were collected by of state assignment "Methodical approaches to the assessment of the structural organization and functioning of forest ecosystems" No. AAAA-A18-1180052590019-7 and results of the study were processed by supported Russian Science Foundation (project 16-17-10284).

\section{References}

Bertemucci P., Coates K.G., Harper K.A. \& Wright E.F., 2002, Gap disturbances in northern old-growth forests of British Columbia, Canada. Journal of Vegetation Science 13(5): 685-696.

Bouche M.B., 1977, Strategies lombriciennes. Ecological Bulletins 25: 122-132.
Cesarz S., Fahrenholz N., Migge-Kleian S., Platner C. \& Schaefer M., 2007, Earthworm communities in relation to tree diversity in a deciduous forest. European Journal of Soil Biology 43(1): 61-67.

Denslow J.S. \& Spies T., 1990, Canopy gaps in forest ecosystems: an introduction. Canadian Journal of Forest Research 20(5): 619-619.

Dupuy J.M. \& Chazdon R.L., 2008, Interacting effects of canopy gap, understory vegetation and leaf litter on tree seedling recruitment and composition in tropical secondary forests. Forest Ecology and Management 255(11): 3716-3725.

Eisenhauer N., Milcu A., Sabais A.C. \& Scheu S., 2008, Animal ecosystem engineers modulate the diversityinvasibility relationship. PLoS One 3(10): e3489.

Evstigneev O.I., 2014, Polivariantnost' sosny obyknovennoj v Brjanskom Poles'e [Ontogenesis polyvariancy of Scotch Pine in Bryansk Polesia]. Russian Forest Science 2: 69-77.

Evstigneev O.I. \& Korotkov V.N., 2016, Pine Forest Succession on Sandy Ridges within Outwash Plain (Sandur) in Nerussa-Desna Polesie. Russian Journal of Ecosystem Ecology 1(3): 1-18.

Frouz J., Liveckova M., Albrechtova J., Chronakova A., Cajthaml T., Pizl V., Hanel L., Stary J., Baldrian P., Lhotakova Z., Simackova H. \& Cepakova S., 2013, Is the effect of trees on soil properties mediated by soil fauna? A case study from post-mining sites. Forest Ecology and Management 309: 87-95.

Gandolfi S., Joly C.A. \& Rodrigues R.R., 2007, Permeability-impermeability: canopy trees as biodiversity filters. Scientia Agricola 64(4): 433-438.

Geraskina A.P., 2019, Transformations of earthworm communities during post-logging successions in the forests of the Northwest Caucasus. Lesovedenie 2(2): $1-14$.

Geraskina A. \& Shevchenko N., 2019, Spatial distribution of the epigeic species of earthworms Dendrobaena octaedra and D. attemsi (Oligochaeta: Lumbricidae) in the forest belt of the northwestern Caucasus. Turkish Journal of Zoology 43(5): 480-489.

Gilyarov M.S., 1975, Metody pochvenno-zoologicheskih issledovanij [Methods of soil and zoological research]. Nauka, Moscow, 304 pp.

Gvozdetsky O.N., 1963, Kavkaz. Ocherki prirody [Caucasus. Essay on nature]. Geografgiz, Moscow, 264 pp.

Haghverdi K., Kiadaliri H., Sagheb-Talebi K.Y. \& Kooch Y., 2012, Variability of plant diversity and soil features following gap creation in Caspian Beech Forests of Iran. Annals of Biological Research 3(9): 4622-4635.

Ignatov M.S., Afonina O.M., Ignatova E.A., Abolina A., Akatova T.V., ... \& Zolotov V.I., 2006, The checklist of mosses of East Europe and North Asia. Arctoa 15: $1-130$. 
Kooch Y. \& Haghverdi K., 2014, Earthworms-good indicators for forest disturbance. Journal of BioScience and Biotechnology 3(2): 155-162.

Kooch Y. \& Hosseini S.M., 2010, Response of earthworms biomass and diversity to windthrow events and soil properties in Hyrcanian forests of Iran. Folia oecologica 37(2): 181-190.

Kooch Y. \& Jalilvand H., 2008, Earthworms as ecosystem engineers and the most important detritivors in forest soils. Pakistan Journal of Biological Sciences 11(6): 819-825.

Landolt E., 1977, Okologische Zeigerwerte zur Schweizer Flora [Ecological pointer values for Swiss flora]. Vol. 64. Veroff. Geobot. Inst. ETH, Zurich, 208 pp.

Lavelle P., Bignell D., Lepage M., Wolters V., Roger P.A., \& Dhillion S., 1997, Soil function in a changing world: the role of invertebrate ecosystem engineers. European Journal of Soil Biology 33(4): 159-193.

Likharev I.M. \& Rammelmeyer E.U., 1952, Nazemnye molljuski fauny SSSR [Ground mollusks of the fauna of the USSR]. AS USSR, Moscow-Leningrad, $511 \mathrm{pp}$.

Lokshina I.E., 1969, Opredelitel' dvuparnonogih mnogonozhek (Diplopoda) ravninnoj chasti Evropejskoj territorij SSSR [Key two-legged millipedes (Diplopoda) of the flat part of the European territory of the USSR]. Nauka, Moscow, 78 pp.

Lukina N.V., Tikhonova E.V., Shevchenko N.E., Gornov A.V., Kuznetsova A.I., ... \& Shanin V.N., 2018, Akkumuljacija ugleroda $\mathrm{v}$ lesnyh pochvah i sukcessionnyj status lesov [Carbon accumulation in forest soils and forest succession status]. KMK, Moscow, 232 pp.

Mamaev B.M., 1972, Opredelitel' nasekomyh po lichinkam: posobie dlja uchitelej [Identifier of insects on larvae: a manual for teachers]. Prosveshhenie, Moscow, 400 pp.

Milkov F.N. \& Gvozdetsky O.N., 1986, Fizicheskaja geografija SSSR. Obshhij obzor. Evropejskaja chast' SSSR. Kavkaz [Physical geography of the USSR. General review. The European part of the USSR. Caucasus]. Vysshaja shkola, Moscow, 376 pp.

Mirkin B.M., Rosenberg G.S. \& Naumova L.G., 1989 , Slovar' ponjatij i terminov sovremennoj fitocenologii [Dictionary of concepts and terms of modern phytocenology]. Nauka, Moscow, 223 pp.

Muscolo A., Bagnato S., Sidari M. \& Mercurio R., 2014, A review of the roles of forest canopy gaps. Journal of Forestry Research 25(4): 725-736.

Nitcenko A.A., 1969, Ob izuchenii jekologicheskoj struktury rastitel'nogo pokrova [On the study of the ecological structure of vegetation]. Botanical Journal 54(7): 1002-1014.

Oldeman R.A.A., 1983, Tropical rain forest: architecture, sylvigenesis and diversity. [in:] S.L. Sutton, T.C. Whitmore, A.C. Chadwick (eds), Tropical rain for- est: ecology and management. Blackwell, Oxford, pp. $139-150$

Orlova M.A., Lukina N.V., Smirnov V.E., Krasnov D.A. \& Kamaev I.O., 2012, Fertility of soils under spruce forests of the Khibiny Mountains. Eurasian soil science 45(6): 612-624.

Rabotnov T.A., 1950, Zhiznennyj cikl mnogoletnih travjanistyh rastenij $\mathrm{v}$ lugovyh cenozah [The life cycle of perennial herbaceous plants in meadow cenoses]. Trudy Botanicheskogo instituta AN SSSR, Series 3. Geobotany 6: 7-204.

Rebertus A.J. \& Veblen T.T., 1993, Structure and tree-fall gap dynamics of old-growth Notofagus forests in Tierra del Fuego, Argentina. Journal of Vegetation Science 4(5): 641-654.

Ritter E., Dalsgaard L. \& Einhorn K.S., 2005, Light, temperature and soil moisture regimes following gap formation in a semi-natural beech-dominated forest in Denmark. Forest Ecology and Management 206(1-3): 15-33.

Romanovsky A.M., 2001, Polivariantnost' ontogeneza Picea abies (Sosnovye) v Brjanskom lesu [Multivariance of the ontogenesis of Picea abies (Pinaceae) in Bryansk woodland]. Botanicheskij Zhurnal 86(8): 72-85.

Runkle J.R., 2000, Canopy tree turnover in old-growth mesic forests of eastern North America. Ecology 81(2): 554-567.

Rysin L.P. \& Rysina G.P., 1966, Opyt populjacionnogo analiza lesnyh soobshhestv [Experience in population analysis of forest communications]. Bulletin of the Moscow Society of Naturalists. Biological Department 21(1): 84-94.

Sariyildiz T. \& Küçük M., 2008, Litter mass loss rates in deciduous and coniferous trees in Artvin, northeast Turkey: Relationships with litter quality, microclimate, and soil characteristics. Turkish Journal of Agriculture and Forestry 32(6): 547-559.

Schumann M.E., White A.S. \& Witham J.W., 2003, The effects of harvest-created gaps on plant species diversity, composition, and abundance in a Maine oakpine forest. Forest ecology and management 176(1-3): 543-561.

Shishov L.L., Tonkonogov V.D., Lebedev A.I. \& Gerasimova M.I., 2004, Klassifikacija i diagnostika pochv Rossii [Classification and diagnostics of Russian soils]. Ojkumena, Smolensk, 342 pp.

Smirnova O.V., 2004, Prirodnaja organizacija biogeocenoticheskogo pokrova lesnogo pojasa Vostochnoj Evropy [The natural organization of the biogeocenotic cover of the forest belt of Eastern Europe], [in:] O.V. Smirnova (ed.), Eastern European forests: history in the Holocene and modernity. Book 1. Nauka, Moscow, p. 16-50.

Smirnova O.V., Chistyakova A.A., Zaugolnova L.B., Evstigneev O.I., Popadiouk R.V. \& Romanovsky A.M., 
1999, Ontogeny of a tree. Botanical Journal 84(12): 8-20.

Smirnova O.V., Khanina L.G. \& Smirnov V.E., 2004, Jekologo-cenoticheskie gruppy rastitel'nosti lesnogo pojasa Vostochnoj Evropy [Ecological and coenotic groups in the vegetation of the forest belt of Eastern Europe], [in:] O.V. Smirnova (ed.), Eastern European forests: history in the Holocene and modernity. Book 1. Nauka, Moscow, p. 165-175.

Smirnova O.V., Bobrovsky M.V., Khanina L.G., 2017, European Russian forests: Their current state and features of their history. Plant and Vegetation. Vol. 15. Springer, Dordrecht: 1-566.

Smirnova O.V., Zaugolgova L.B., Khanina L.G., Bobrovsky M.V. \& Toropova N.A., 2002, Populjacionnye i fitocenoticheskie metody analiza bioraznoobrazija rastitel'nogo pokrova [Population and phytocenotic methods for the analysis of biodiversity of the plant cover], [in:] Conservation and restoration of biodiversity. Izdatel'stvo Nauchno-obrazovatel'nogo centra, Moscow, pp. 145-194.

Uranov A.A., 1975, Vozrastnoj spektr fitocenopopuljacij kak funkcija vremeni i jenergii volnovyh processov [Age spectrum of phytocenopopulations as a function of time and energy wave processes]. Biological Sciences 2: 7-34.

Uranov A.A. \& Smirnova O.V., 1969, Klassifikacija i osnovnye cherty razvitija populjacij mnogoletnih rastenij [Classification and main features of perennial plant populations]. Bulletin of the Moscow Society of Naturalists. Biological Department 74(2): 119-134.
Vajari K.A., Jalilvand H., Pourmajidian M.R., Espahbodi K. \& Moshki A., 2012, Effect of canopy gap size and ecological factors on species diversity and beech seedlings in managed beech stands in Hyrcanian forests. Journal of Forestry Research 23(2): 217-222.

Vsevolodova-Perel T.S., 1997, Dozhdevye chervi fauny Rossii: kadastr i opredelitel' [Earthworms of the fauna of Russia: Cadastre and determinant]. Nauka, Moscow, $101 \mathrm{pp}$.

Watt A.S., 1947, Pattern and process in plant community. Journal of Ecology 35: 1-22.

Whitmore T.C., 1990, An introduction to tropical rain forests. Oxford University Press, Oxford, 226 pp.

WRB, World reference base for soil resources, 2015, International soil classification system for naming soils and creating legends for soil maps. World Soil Resources Reports No 106. FAO, Rome, 192 pp.

Yamamoto S.I., 2000, Forest gap dynamics and tree regeneration. Journal of Forest Research 5(4): 223-229.

Zaugolnova L.B., Zhukova L.A., Komarov A.S. \& Smirnova O.V., 1988, Cenopopuljacii rastenij (ocherki po populjacionnoj biologii) [Coenopopulations of plants (essays on population biology)]. Nauka, Moscow, $236 \mathrm{pp}$.

Zhang C., Zou C.J., Peltola H., Wang K.Y. \& Xu W.D., 2013, The effects of gap size and age on natural regeneration of Picea mongolica in the semi-arid region of Northern China. New Forests 44(2): 297-310.

World Flora Online, 2012, online version at http://www. worldfloraonline.org/ [Accessed: 12.11.2020)]. 